\title{
O CASO BELO MONTE: DESENVOLVIMENTO HUMANO DE POVOS INDÍGENAS E TECNOPOLÍTICA DE GERAÇÃO DE ENERGIA ${ }^{1}$
}

\author{
BELO MONTE LEADING CASE: INDIGENOUS PEOPLES' HUMAN DEVELOPMENT AND TECHNO- \\ POLITICS OF ENERGY GENERATION²
}

\author{
Eduardo Faria Silva ${ }^{3}$ \\ Anderson Marcos Santos ${ }^{4}$
}

Resumo: $O$ presente estudo de caso está dividido em quatro momentos. O primeiro momento destina-se à apresentação do histórico político-institucional da Usina de Belo Monte, no Pará. O segundo momento expõe os detalhes da Ação Civil Pública, ajuizada pelo Ministério Público Federal, e que contesta os procedimentos formais e materiais que autorizaram os estudos ambientais e antropológico de oitiva das comunidades afetadas, nos termos do $\int 3^{\circ}$ do art. 231 da Constituição Federal. A ação foi escolhida como objeto de estudo, pois foi a primeira medida judicial que teve uma decisão do Supremo Tribunal Federal autorizando os estudos sob o fundamento de possível lesão à ordem pública e à economia pública. $\bigcirc$ terceiro momento articula o conteúdo das decisões proferidas pelo Poder Judiciário no trâmite da Ação Civil Pública, com destaque à posição da Corte Constitucional. O quarto momento apresenta considerações técnico-jurídicas que foram extraídas da análise dos documentos que compunham o presente estudo.

Palavras-chave: Direito. Tecnopolítica. Desenvolvimento Humano. Megaobras. Indígenas.

\begin{abstract}
This case study is divided in four parts. The first part is intended to present Belo Monte Power Plant's political-institutional background. The second part unfolds the details of the Public Civil Action, filed by the Federal Prosecution Service, which contests the formal and material procedures that authorized both environmental and affected communities' hearing anthropological studies, according to the $₫ 3$ of Art. 231 of the Federal Constitution. The action was chosen as the object of the present study because it was the first judicial measure having a Supreme Court decision authorizing such studies on the grounds of possible injury to public order and public economy. The third part articulates the content of the decisions given by the judiciary during the procedures of the Public Civil Action, with emphasis to the Constitutional Court's position on the issue. The fourth part presents technical-juridical considerations that were extracted from the analysis of the documents that composed this study.
\end{abstract}

Keywords: Law. Techno-politics. Human development. Megaprojects. Indigenous peoples.

\footnotetext{
1 O presente estudo de caso é um aprofundamento da pesquisa realizada e financiada pela Fundação Ford, entre os anos 2012 e 2015. Projeto n. 2995.

2 This leading case is a further development of the research made and financed by the Ford Foundation, between 2012 and 2015. Project n. 2995.

3 Doutor e Mestre em Direito pela Universidade Federal do Paraná; Professor Titular de Direito Constitucional na Universidade Positivo; eduardo.faria.silva@up.edu.br

4 Doutor em Sociologia pela Universidade Estadual de Campinas; Mestre em Direito pela Universidade Federal do Paraná; Professor de Sociologia e Antropologia na Universidade Positivo; Rua Professor Pedro Viriato Parigot de Souza, 5300, Cidade Industrial, 81280-330, Curitiba, Paraná, Brasil; andermsantos@hotmail.com
} 


\section{Introdução técnica do estudo de caso}

O presente estudo de caso está dividido em quatro momentos. O primeiro momento destina-se à apresentação do histórico político-institucional da Usina de Belo Monte, no Pará. O segundo momento expõe os detalhes da Ação Civil Pública, ajuizada pelo Ministério Público Federal, e que contesta os procedimentos formais e materiais que autorizaram os estudos ambientais e antropológico de oitiva das comunidades afetadas, nos termos do $\int 3^{\circ}$ do art. 231 da Constituição Federal. A ação foi escolhida como objeto de estudo, pois foi a primeira medida judicial que teve uma decisão do Supremo Tribunal Federal autorizando os estudos, sob o fundamento de possível lesão à ordem pública e à economia pública. O terceiro momento articula o conteúdo das decisões proferidas pelo Poder Judiciário no trâmite da Ação Civil Pública, com destaque à posição da Corte Constitucional. O quarto momento apresenta considerações técnico-jurídicas que foram extraídas da análise dos documentos que compunham o presente relatório.

\section{Histórico político-institucional da Usina Hidrelétrica de Belo Monte, Estado do Pará}

O Pará, localizado na região Norte do Brasil e dentro da área da Amazônia Legal, ${ }^{5}$ é um importante e estratégico estado da federação sob o ponto de vista econômico, considerando a sua localização, extensão e concentração de recursos naturais e hídricos. Ele tem a segunda maior extensão territorial do País, com uma área de 1.247.954,666 km² e uma população estimada, em 2013, de 7.969.654 de habitantes (IBGE, 2017). A combinação de ambas as informações indica uma baixa densidade demográfica de 6,07 habitantes por quilômetro quadrado (IBGE, 2015).

\footnotetext{
5 A Amazônia Legal "é uma área que corresponde a 59\% do território brasileiro e engloba a totalidade de oito estados (Acre, Amapá, Amazonas, Mato Grosso, Pará, Rondônia, Roraima e Tocantins) e parte do Estado do Maranhão (a oeste do meridiano de $44^{\circ} \mathrm{W}$ ), perfazendo 5,0 milhões de $\mathrm{km}^{2}$. Nela residem $56 \%$ da população indígena brasileira. $\bigcirc$ conceito de Amazônia Legal foi instituído em 1953 e seus limites territoriais decorrem da necessidade de planejar o desenvolvimento econômico da região e, por isso, não se resumem ao ecossistema de selva úmida, que ocupa 49\% do território nacional e se estende também pelo território de oito países vizinhos. Os limites da Amazônia Legal foram alterados várias vezes em consequência de mudanças na divisão política do país. O Plano Amazônia Sustentável (PAS), lançado em maio deste ano pelo governo federal, considera integralmente o Estado do Maranhão como parte da Amazônia Brasileira." (INSTITUTO DE PESQUISA ECONÔMICA APLICADA, 2008).
} 
Mapa 1 - Estado do Pará, localizado na região Norte do País

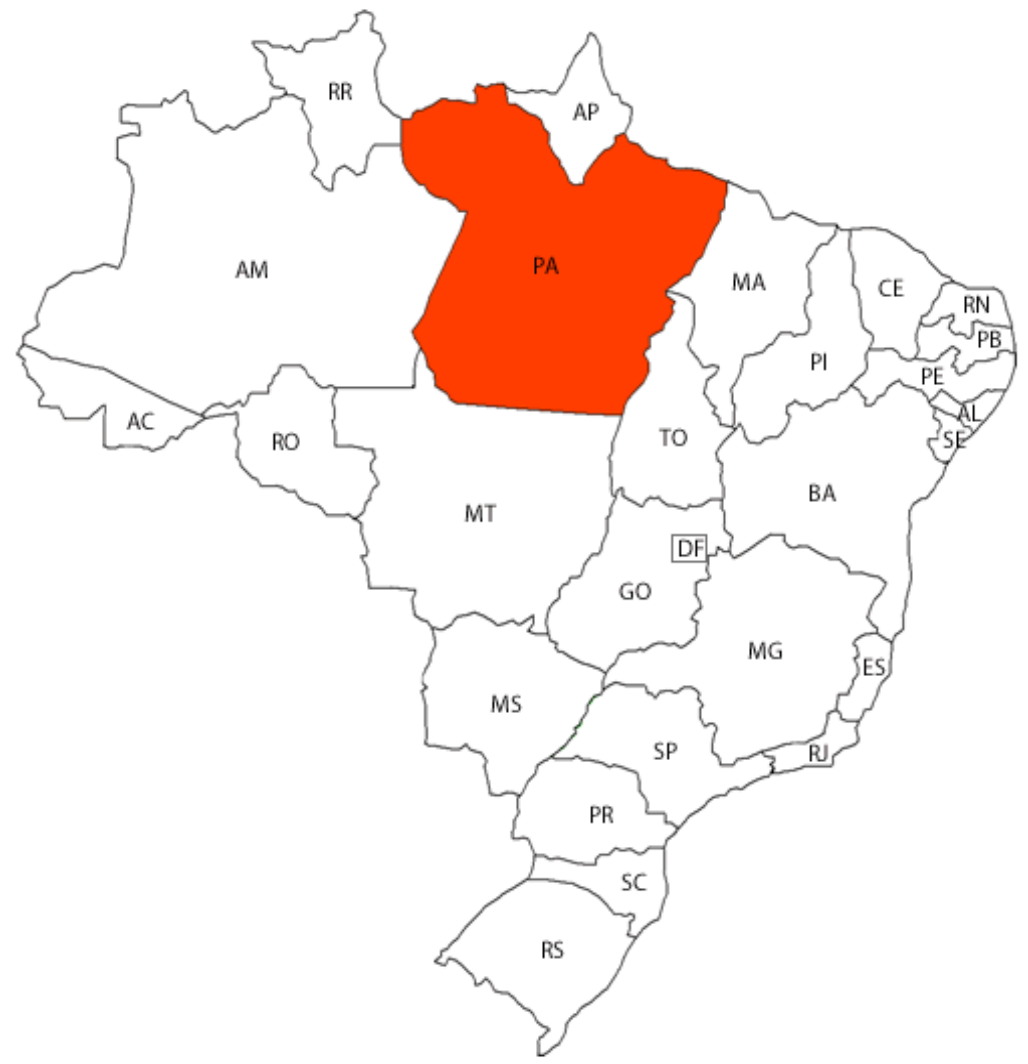

Fonte: Governo do Estado do Pará (PARÁ, 2012).

Em relação aos recursos hídricos, a unidade da federação tem um dos maiores potenciais hidroenergéticos da nação, proporcionado pelas águas do Rio Xingu, que é classificado como a Sub-bacia 18 da Bacia Hidrográfica do Amazonas. O Xingu, que nasce no Estado do Mato Grosso e deságua no Rio Amazonas, no Pará, é um rio federal ${ }^{6}$ que corresponde a 12,7\% do potencial hidrelétrico inventariado ${ }^{7}$ brasileiro (AGÊNCIA NACIONAL DE ENERGIA ELÉTRICA, 2016). ${ }^{8}$

6 O inciso III, do artigo 20, da Constituição Federal define que os rios que banhem mais de um Estado são bens da União (BRASIL, 2000).

7 O potencial inventariado "é resultante da somatória dos aproveitamentos: • Apenas em inventário - resultado de estudo da bacia hidrográfica, realizado para a determinação do seu potencial hidrelétrico, mediante a escolha da melhor alternativa de divisão de queda, caracterizada pelo conjunto de aproveitamentos compatíveis entre si e com projetos desenvolvidos, de forma a se obter uma avaliação da energia disponível, dos impactos ambientais e dos custos de implantação dos empreendimentos; • Com estudo de viabilidade - resultado da concepção global do aproveitamento, considerando sua otimização técnico-econômica que permita a elaboração dos documentos para licitação. Esse estudo compreende o dimensionamento das estruturas principais e das obras de infra-estrutura local e a definição da respectiva área de influência, do uso múltiplo da água e dos efeitos sobre o meio ambiente; - Com projeto básico - aproveitamento detalhado e em profundidade, com orçamento definido, que permita a elaboração dos documentos de licitação das obras civis e do fornecimento dos equipamentos eletromecânicos; • Em construção - aproveitamento que teve suas obras iniciadas, sem nenhuma unidade geradora em operação; e - Em operação - os empreendimentos em operação constituem a capacidade instalada. Os aproveitamentos somente são considerados para fins estatísticos nos estágios 'inventário', 'viabilidade' ou 'projeto básico', se os respectivos estudos tiverem sido aprovados pelo poder concedente." (AGÊNCIA NACIONAL DE ENERGIA ELÉTRICA, 2016).

8 Em 2003, "o potencial hidrelétrico brasileiro consistia em cerca de 260 GW. Contudo apenas 68\% desse potencial foi inventariado (Tabela 4.1). Entre as bacias com maior potencial destacam-se as do Rio Amazonas e do Rio Paraná." (AGÊNCIA 
A magnitude do potencial de geração hidrelétrica da Bacia Hidrográfica do Amazonas corresponde a 40,5\% do total do País e, ao contrário das bacias do Sul e Sudeste, ainda foi pouco explorada para a geração de energia (BRASIL, 2011).

Mapa 2 - Potencial hidrelétrico brasileiro por sub-bacia hidrográfica - situação em março de 2003

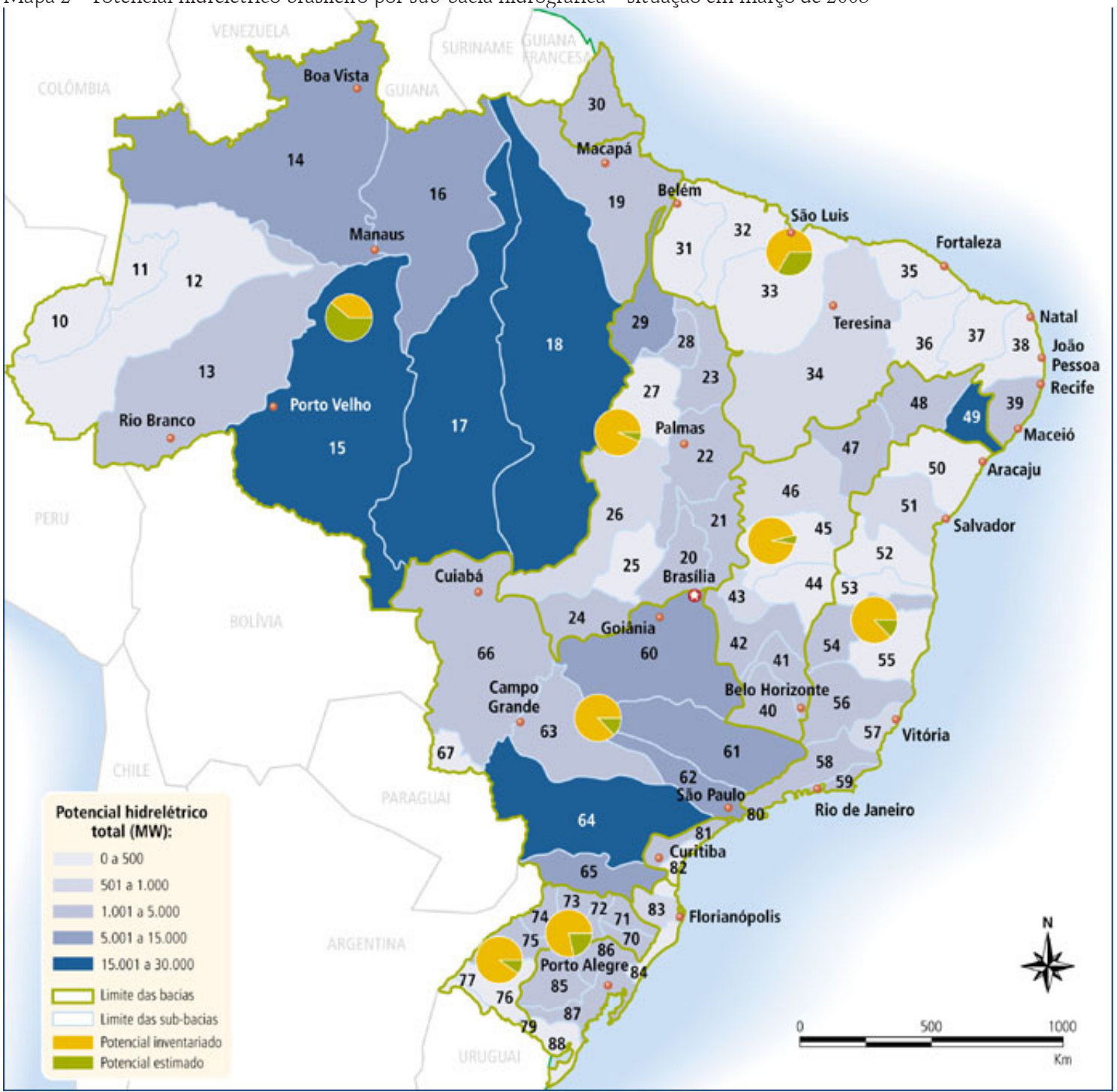

Fonte: Centrais Elétricas Brasileiras (2003).

Nota: os números correspondem aos códigos das sub-bacias (AGÊNCIA NACIONAL DE ENERGIA ELÉTRICA, 2016).

O fato apresentado faz com que o território do Pará, aliado às grandes extensões de áreas com pouca densidade demográfica, integre, há mais de 40 anos, a política nacional de energia e torne-se, nos últimos 20 anos, prioridade nas ações de aproveitamento do potencial pelo governo federal.

NACIONAL DE ENERGIA ELÉTRICA, 2016). 
Entre as diversas obras ligadas ao setor, destaca-se a construção da Usina Hidrelétrica de Belo Monte, em virtude da potência de geração a ser instalada, cuja previsão oficial é 11.181 mil megawatts, em razão dos recursos financeiros investidos, que ultrapassam a cifra de 30 bilhões de reais, e dos impactos sociais, culturais e ambientais envolvidos, que atingem diretamente os povos tradicionais e o bioma da Amazônia.

Os estudos sobre o Inventário Hidrelétrico da Bacia Hidrográfica do Rio Xingu iniciam, em 1975, ligados ao projeto desenvolvimentista da ditadura militar brasileira. A Centrais Elétricas do Norte do Brasil (Eletronorte S/A), subsidiária da Centrais Elétricas Brasileiras (Eletrobrás), é a empresa estatal que contratou o Consórcio Nacional de Engenheiros Consultores S/A (CNEC), ligado, até o ano 2009, ao Grupo Camargo Corrêa, para realizar os estudos de inventário da bacia do rio (CENTRAIS ELÉTRICAS BRASILEIRAS, 2006).

Este trabalho é concluído em janeiro de 1980 e aprovado pelo Departamento Nacional de Águas e Energia Elétrica (DNAEE), que posteriormente será substituído pela Agência Nacional de Energia Elétrica (Aneel). Os seus resultados apontam que:

[para o] aproveitamento integral da Bacia do Rio Xingu, foram previstos sete barramentos, que gerariam 19 mil megawatts (MW), metade da capacidade instalada nas hidrelétricas brasileiras à época. Essas usinas representariam o alagamento de

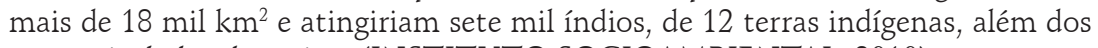
grupos isolados da região. (INSTITUTO SOCIOAMBIENTAL, 2010).

A Eletronorte, naquele mesmo ano e com fundamento nas recomendações dos Estudos Finais de Inventário, inicia os estudos de viabilidade do aproveitamento do Complexo Hidrelétrico de Altamira, que reunia a Usina Hidrelétrica de Babaquara, com previsão de potência instalada de 6.273,96 ou 4.791,80 megawatts, e a Usina Hidrelétrica Kararaô, com previsão de potência instalada de 8.380,80 ou 6.964,60 megawatts, as quais, juntas, considerando-se a alternativa A ou B, respectivamente, na indicação de aproveitamento do inventário, produziriam 14.654,76 ou 11.756,40 megawatts (CENTRAIS ELÉTRICAS BRASILEIRAS, 2006, p. 17).

A prioridade nos estudos de viabilidade sofreu uma adequação, em 1987, com o Plano Nacional de Energia Elétrica 1987-2010 - Plano 2010, aprovado pelo Decreto n. 96.652, de 6 de setembro de 1988, assinado pelo Presidente José Sarney. O Plano apresentava as construções de usinas que ocorreriam até 2010, conforme descrição a seguir: 


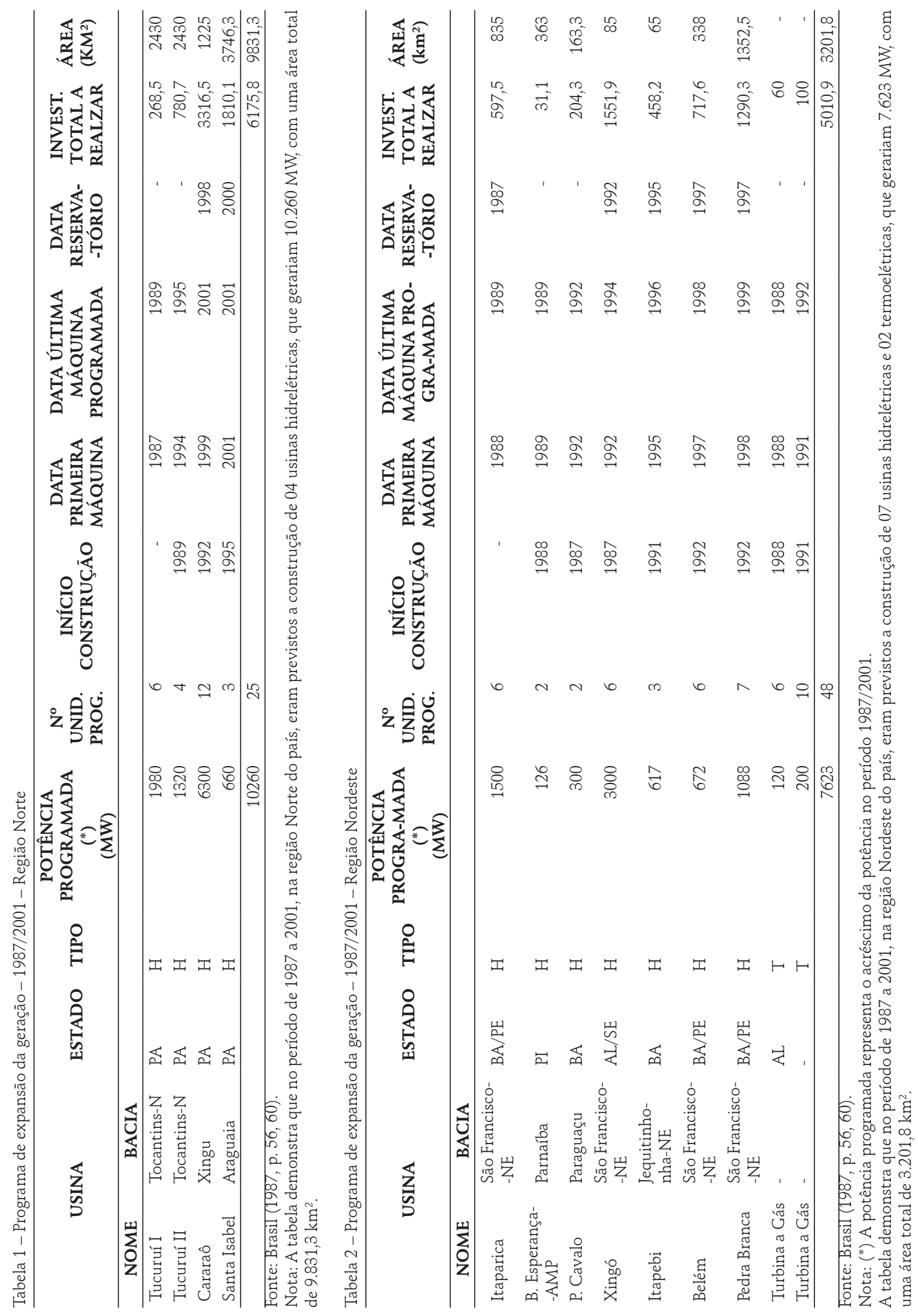




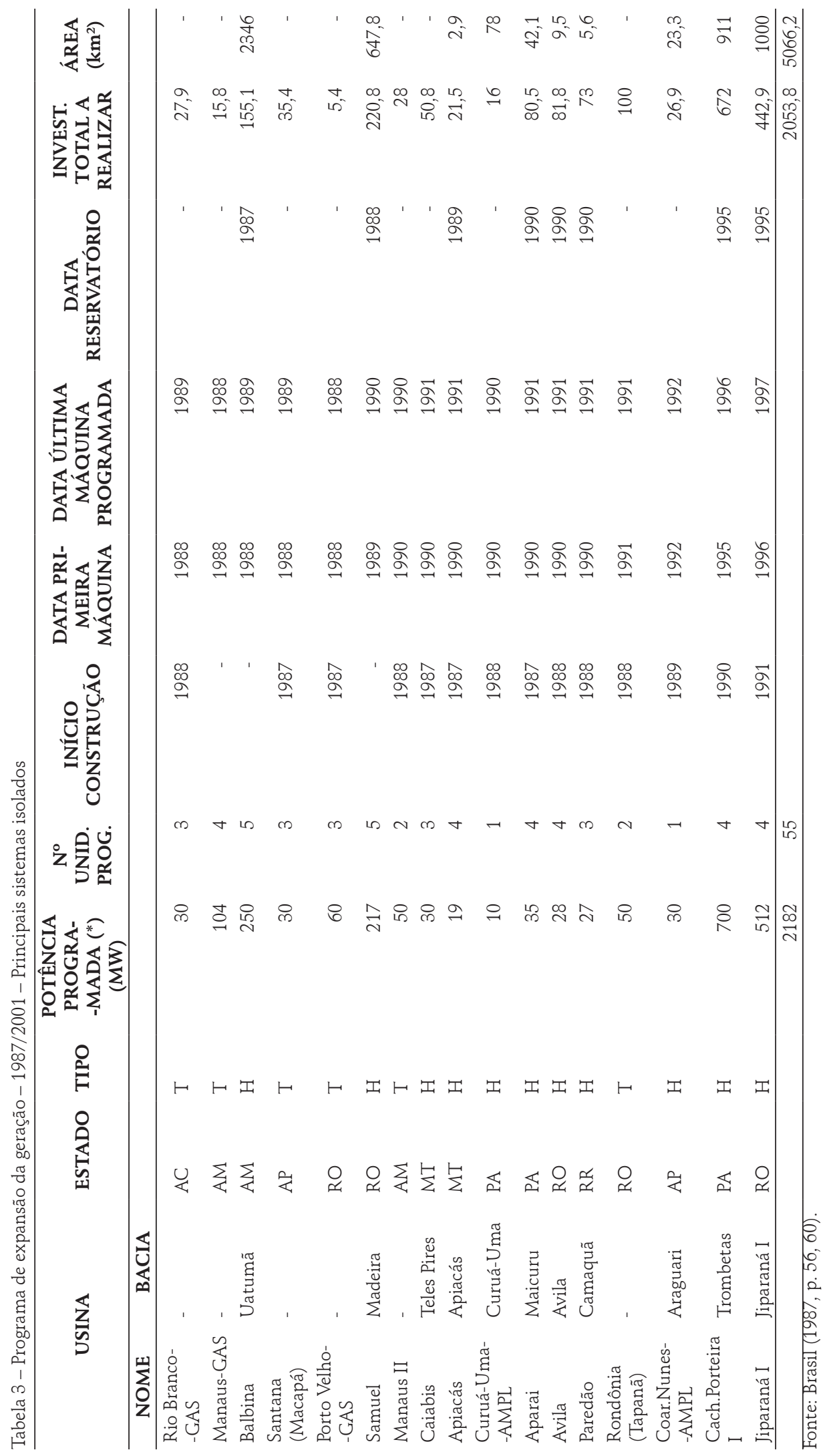


Além disso, o Plano Nacional de Energia 1987/2010 apontava Kararaô, em substituição à Babaquara, como o empreendimento comercial prioritário para o setor e que iria compor o Sistema Brasileiro Interligado, a partir do seu funcionamento projetado para 1999. O Plano 2010 previa que Kararaô seria a maior usina a ser construída no Brasil, com uma potência programada de 6.300 megawatts e um reservatório de 1.225 km² (BRASIL, 2005, p. 56), "com interferências significativas na área indígena Paquiçamba, além de grande parte do vale do rio Bacajá." As reações dos povos tradicionais da Amazônia contra o projeto foram imediatas e o governo renomeou o projeto para Belo Monte.

As empresas responsáveis pelo Relatório Final dos Estudos de Viabilidade do Aproveitamento Hidrelétrico de Belo Monte entregaram suas análises no fim de 1988 e os respectivos estudos ambientais no início de 1989 (CENTRAIS ELÉTRICAS BRASILEIRAS, 2006, p. 19); a Eletronorte enviou os documentos para o DNAEE, em 1990, com o objetivo de ter a aprovação e a outorga de concessão.

Os conflitos sociais com os povos tradicionais e ambientalistas e a necessidade de readequação da atratividade econômica forçou que, em junho de 1993, o DNAEE e a Eletrobrás apresentassem novas diretrizes para a o andamento do projeto do Complexo de Belo Monte. A revisão dos estudos buscava

a viabilização sociopolítica do empreendimento, com ênfase à reavaliação dos estudos energéticos e à atualização dos estudos hidrológicos, ambientais e de custo. As atividades a serem desenvolvidas visariam, além de viabilizar sociopoliticamente o empreendimento, subsidiar as decisões relativas à retomada do projeto do AHE Belo Monte no contexto e no horizonte do Plano 2015 da Eletrobrás. (CENTRAIS ELÉTRICAS BRASILEIRAS, 2006, p. 17).

O DNAEE, por meio da Portaria n. 769, de 25 de novembro de 1994, criou o grupo de trabalho formado por técnicos do seu quadro próprio, da Eletronorte, Eletrobrás, com o escopo de revisar a estrutura dos estudos já realizados para confirmar a atratividade econômica da usina, atualizar os estudos ambientais, hidrológicos e orçamentários, e propor medidas de sustentação sociopolítica para o empreendimento (CENTRAIS ELÉTRICAS BRASILEIRAS, 2006, p. 17; PEREIRA, 2013, p. 19). As análises do grupo de trabalho apontaram para a alteração do sítio de barramento, "trazendo-o para montante, com a implantação de canais, na margem esquerda do rio Xingu, que, em conjunto com os talvegues naturais e diques auxiliares, constituiriam os canais de adução da usina." (CENTRAIS ELÉTRICAS BRASILEIRAS, 2006, p. 18). A inovação permitiu: "minimizar os impactos ambientais e de qualidade da água no rio Bacajá; eliminar a interferência do reservatório com a área indígena Paquiçamba; diminuir a área de inundação do reservatório do AHE Belo Monte, minimizando os impactos e os custos com relocações." (CENTRAIS ELÉTRICAS BRASILEIRAS, 2006, p. 18).

As figuras constantes da Atualização do Inventário Hidrelétrico da Bacia do Rio Xingu demonstram que o projeto de construção de Belo Monte, ao longo dos anos, sofreu significativa alteração e a área inundada do reservatório passou de $1.225 \mathrm{~km}^{2}$ para $440 \mathrm{~km}^{2}$, fato que reduziu os impactos sociopolíticos e ambientais (FIGUEIRA NETTO; FRANCO; REZENDE, 2007, p. 1). 
Mapa 3 - Configuração do Complexo Hidrelétrico de Altamira AHE Belo Monte e AHE Altamira

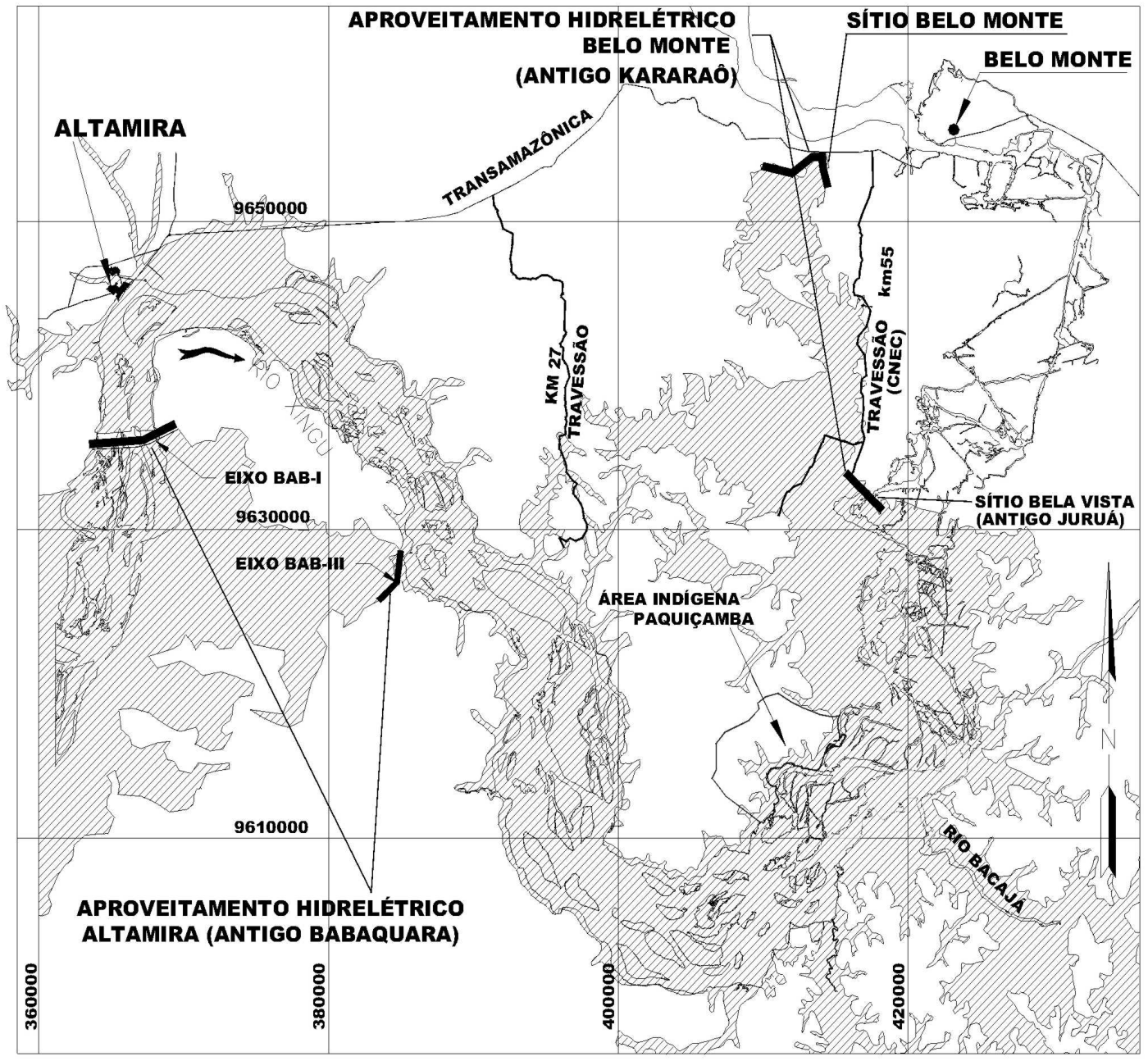

Fonte: Centrais Elétricas Brasileiras (2006, p. 18). 
Mapa 4 - Configuração do Complexo Hidrelétrico Belo Monte Usina Principal, no Sítio Belo Monte, e Usina Complementar, no Sítio Pimental

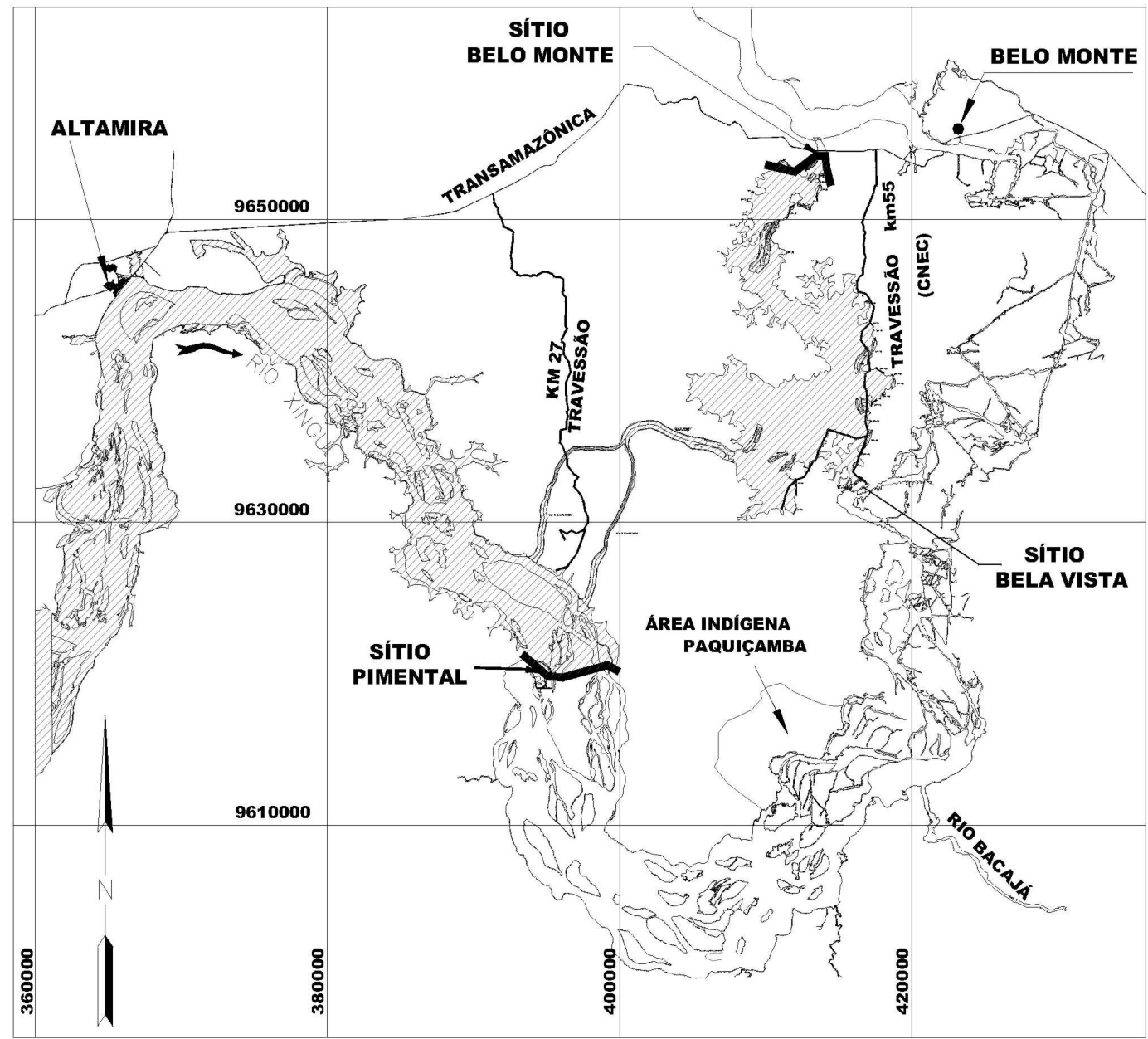

Fonte: Centrais Elétricas Brasileiras (2006, p. 19).

Em dezembro de 2000, a Eletrobrás e a Eletronorte firmam acordo de cooperação técnica para selar o começo das atividades da $2^{a}$ Etapa dos Estudos de Viabilidade do AHE Belo Monte, que tinha como orientação o ponto do barramento principal e o órgão extravasor. ${ }^{9}$

Na fase de Estudos Preliminares da $2^{\text {a }}$ Etapa dos Estudos de Viabilidade do aproveitamento de Belo Monte foi feita a definição do sítio de barramento principal, que deveria estar localizado no trecho compreendido entre a entrada dos canais e a foz do rio Bacajá, com extensão de $45 \mathrm{~km}$, aproximadamente, sendo que, no eixo

\footnotetext{
9 O percurso que resultou na $2^{\text {a }}$ Etapa dos Estudos de Viabilidade do AHE Belo Monte iniciou formalmente em 10 de dezembro de 1998. "[...] a Eletrobrás solicitou à ANEEL, pela carta CTA-DP-010605/98, autorização para a realização dos Estudos de Viabilidade do AHE Belo Monte, em conjunto com a Eletronorte e associações com empresas privadas, através de convênios, aproveitando-se os estudos anteriormente executados. A Superintendência de Gestão dos Potenciais Hidráulicos da ANEEL deu abertura ao processo n. 27100.000057/88-70 e registrou tal solicitação, conforme ofício n. 060/1999-SPH/ANEEL de 11/02/1999. Essa decisão teve como desdobramento o Acordo de Cooperação Técnica firmado, entre a ELETROBRÁS e a ELETRONORTE em dezembro de 2000 que possibilitou a realização da $2^{\text {a }}$ Etapa dos Estudos de Viabilidade do AHE Belo Monte, perseguindo novas concepções para o empreendimento hidrelétrico, que fundamentalmente minimizassem os impactos socioambientais a ele associados." (CENTRAIS ELÉTRICAS BRASILEIRAS, 2007, p. 1-4).
} 
de barramento principal, estaria posicionado o órgão extravasor, com capacidade de escoar a cheia de projeto. Com base nas informações então disponíveis - restituição aerofotogramétrica, fotos aéreas e imagens de satélite - foram identificados três sítios com maior atratividade para barramento: o primeiro, situado cerca de $2 \mathrm{~km}$ a jusante da entrada dos canais, denominado Sítio Pimental; o segundo, situado cerca de $10 \mathrm{~km}$ a jusante do anterior, que recebeu a denominação de Sítio Tucunaré e o terceiro, próximo à Ilha da Fazenda, localizado $15 \mathrm{~km}$ a jusante do primeiro sítio, denominado Sítio Fazenda. (CENTRAIS ELÉTRICAS BRASILEIRAS, 2006, p. 19).

As orientações seguidas destacaram os três barramentos que guiariam os estudos subsequentes e, ao final, indicariam qual seria mais atrativo para o empreendimento. Estes foram denominados, respectivamente, como Sítio Pimental, Sítio Tucunaré e Sítio Fazenda e apresentavam as seguintes características:

Todos os três sítios têm como características comuns o vertedouro de superfície com elevado grau de submergência para a vazão de projeto e desvio concebido para ser efetuado em duas fases: a primeira com estrangulamento da calha e a segunda com o rio passando pelo órgão extravasor. Em relação aos arranjos, nos Sítios Pimental e Tucunaré, o vertedouro se situa na região central da calha, enquanto que no Sítio Fazenda, a estrutura extravasora estaria situada na margem esquerda. Para as três alternativas, o fechamento do vale deverá ser complementado por barragens de terra/enrocamento com os seguintes comprimentos de crista: $2,2 \mathrm{~km}$ para o Sítio Pimental, $3,3 \mathrm{~km}$ para o Sítio Tucunaré e 3,8 km para o Sítio Fazenda. A altura média das estruturas de concreto e terra/enrocamento aumento, quanto mais a jusante estiver o sítio de barramento, pela ordem, Sítios Pimental, Tucunaré e Fazenda, mas, por outro lado, diminui o número de vãos do vertedouro, em função da redução da submergência das soleiras vertentes. Em relação aos canais de adução, a concepção adotada é comum para os três sítios, sendo considerados dois canais paralelos, escavados em solo e rocha, com as mesmas características geométricas, com cerca de $11 \mathrm{~km}$ de extensão cada. O Sítio Fazenda tinha como maior atrativo o fato de possuir um menor desenvolvimento de crista das estruturas de concreto, mercê do menor número de vãos do vertedouro necessários para esta alternativa. Entretanto, identificou-se de imediato a interferência direta com a comunidade de moradores locais e o garimpo, sendo adotada como premissa de projeto que a primeira teria que ser obrigatoriamente relocada e o segundo desativado. Por seu turno, o Sítio Pimental apresentava como principal vantagem a menor altura média das estruturas de concreto e de solo/enrocamento. Além disso, vislumbravam-se, neste último, algumas facilidades construtivas, por apresentar um melhor equilíbrio entre as diversas fases de desvio do rio. Como vantagem adicional, identificava-se que este sítio possuía menor área de inundação, comparado aos outros estudados. A desvantagem aparente desta alternativa de sítio, qual seja necessitar uma maior extensão de crista do vertedouro, ficou minimizada pelo fato do bloco típico desta estrutura ter volume de concreto relativamente reduzido. Para esta situação, a diferença de custo por metro de crista entre as estruturas de concreto e as de terra/enrocamento se manteve abaixo da tradicionalmente aceitada. O cotejamento das diversas variáveis consideradas nos três sítios estudados na calha do rio Xingu, indicou ser o Sítio Pimental o mais adequado entre as alternativas estudadas, recomendando-se a sua seleção para o desenvolvimento dos estudos subsequentes. (CENTRAIS ELÉTRICAS BRASILEIRAS, 2006, p. 20).

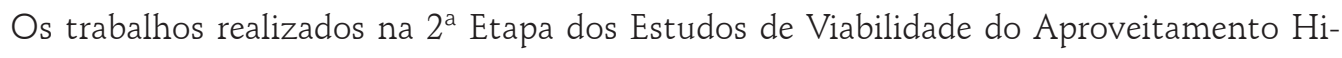
drelétrico de Belo Monte indicaram que haveria uma "vantagem técnica e econômica para implantação de uma Casa de Força Complementar, para aproveitar energeticamente as vazões remanescentes 
ao longo da Volta Grande ('descarga sanitária'), a jusante do barramento principal da calha do rio Xingu." (CENTRAIS ELÉTRICAS BRASILEIRAS, 2006, p. 20).

A combinação da Usina Principal de Belo Monte, com 11 mil megawatts de potência instalada, e a Casa de Força Complementar, com 181 megawatts de potência instalada, que juntas representam 11.181 megawatts de potência instalada, é que passou a ser denominada como Aproveitamento Hidrelétrico de Belo Monte - AHE Belo Monte. ${ }^{10}$ Tal circunstância, que aproveita duas usinas para o potencial hidrelétrico, consolida e justifica o nome "Complexo Hidrelétrico de Belo Monte" (CENTRAIS ELÉTRICAS BRASILEIRAS, 2006, p. 20-21).

Em relação aos Estudos de Impacto Ambiental (EIA) e o Relatório de Impacto Ambiental (Rima) do Complexo Hidrelétrico de Belo Monte, a Eletronorte, em 2000, contratou a Fundação de Amparo e Desenvolvimento de Pesquisas (Fadesp) para elaborar o trabalho. A entidade, vinculada à Universidade Federal do Pará (UFPA), foi impedida de realizar o trabalho, em setembro de 2001, em consequência da Ação Civil Pública ajuizada pelo Ministério Público Federal do Estado do Pará. A medida judicial sustentava que a Fadesp não poderia ser contratada sem licitação pela Eletrobrás e que a entidade não teria competência para realizar o EIA/Rima. O Instituto Brasileiro do Meio Ambiente dos Recursos Naturais Renováveis (Ibama) é que deveria acompanhar a elaboração do EIA/Rima e licenciar a obra, pois o Rio Xingu é bem da União e o relatório, que deveria examinar toda a bacia do Xingu de forma integrada, estaria sob sua competência. Além disso, havia falta de participação do Instituto do Patrimônio Histórico e Artístico Nacional (IPHAN) nos Termos de Referência para os estudos arqueológicos e falta de aprovação do Congresso Nacional para a obra, pois se trata de terra indígena (art. 231, parágrafo $6^{\circ}$, da Constituição Federal) (MINISTÉRIO PÚBLICO FEDERAL, 2001).

A suspensão judicial do EIA/Rima fez com a que a Eletrobrás e a Eletronorte enviassem para a Aneel, em fevereiro de 2002, o Relatório Final dos Estudos de Viabilidade da UHE Belo Monte sem os respectivos estudos ambientais. Nesse sentido, o Congresso Nacional, por meio do Decreto Legislativo n. 788, de 13 de julho de 2005, assinado pelo representante das Casas do Legislativo, Renan Calheiros, autoriza o Poder Executivo a implantar o Aproveitamento Hidrelétrico de Belo Monte, localizado em trecho do Rio Xingu, denominado "Volta Grande do Xingu", no Pará, a ser desenvolvido após estudos de viabilidade técnica, econômica, ambiental e outros que a Eletrobrás considerar necessários (CONGRESSO NACIONAL, 2005).

\footnotetext{
$\overline{10}$ O Prof. Oswaldo Sevá Filho, da Unicamp, realiza uma simulação das potências hidráulicas do Rio Xingu, considerando se a usina estivesse em atividade entre 1931 e 1996. A simulação usou o modelo Hydrolab (CICOGNA; SOARES, 2003, FEEC, Unicamp) que foi alimentado pela base de dados do SIPOT - Sistema de Informações do Potencial Hidrelétrico, da Eletrobrás), que informa os valores numéricos da vazão d'água do Rio Xingu em Altamira, mensurados in loco ou extrapolados, desde o ano de 1931 até o ano de 1996. Destacamos o subperíodo de 1949 a 1956, por ser considerado o de melhor pluviosidade, do ponto de vista da geração hidrelétrica nos rios brasileiros do hemisfério Sul. Não se trata, portanto, de afirmar quanto da sua potência instalada, tais usinas poderiam no futuro acionar, e sim, trata-se de deduzir como elas teriam funcionado no passado, se existissem nesses pontos desses rios que apresentaram essas vazões. Neste item apenas resumimos os números das simulações feitas para três tipos de situações hipotéticas. Nesse sentido, uma usina hipotética que aproveitasse apenas a bacia do Rio Xingu, de 1931 a 1996, teria a potência máxima assegurada de 1.356 megawatts (SEVÁ FILHO, 2005, p. 16-17).
} 
A norma determina que, dentre outros, os estudos deveriam abranger o Estudo de Impacto Ambiental (EIA), o Relatório de Impacto Ambiental (Rima), a Avaliação Ambiental Integrada (AAI) da bacia do Rio Xingu, e o estudo de natureza antropológica, atinente às comunidades indígenas localizadas na área sob influência do empreendimento, devendo, nos termos do $₫ 3^{\circ}$ do art. 231 da Constituição Federal, ser ouvidas as comunidades afetadas.

Com fundamento no Decreto Legislativo n. 788/2005, em agosto de 2005, é assinado um Acordo de Cooperação Técnica entre a Eletrobrás e as construtoras privadas Andrade Gutierrez, Camargo Correa e Norberto Odebrecht, denominado ECE n. 120/2005. ${ }^{11}$ O instrumento objetivava a conclusão "dos Estudos de Viabilidade Técnica, Econômica e Socioambiental do Aproveitamento Hidrelétrico Belo Monte, incluindo a revisão do inventário do trecho principal do rio Xingu." O registro ativo para a revisão do inventário foi requerido pela Eletrobrás à ANEEL, em 9 de agosto de 2005, e o seu deferimento foi formalizado por meio do Despacho n. 1.380, de 29 de setembro de 2005, publicado no Diário Oficial da União, em 30 de setembro de 2005, "que estabelecia as condições para a realização do reinventário, inclusive com a necessidade de se considerar os estudos de viabilidade do AHE Belo Monte, em análise na agência." (CENTRAIS ELÉTRICAS BRASILEIRAS, 2007, p. 1-5).

Em março de 2006, o Ministério Público Federal do Pará ajuíza Ação Civil Pública Ambiental, registrada sob n. 2006.39.03.000711-8, contra a Eletrobrás, Eletronorte, Ibama e Funai. ${ }^{12}$ A medida, que teve liminar deferida, buscava a anulação do Decreto Legislativo n. 788/2005 e pretendia assegurar a oitiva prévia dos povos indígenas, consoante dispositivo constitucional referente ao tema. ${ }^{13} \mathrm{O}$ Juiz Federal Herculano Nacif revoga a liminar e é interposto pelo MPF recurso de agravo de instrumento, sob o n. 2006.01.00.017736-8/PA, para o Tribunal Regional da $1^{\text {a }}$ Região - TRF1 a . A Desembargadora-relatora Selene Almeida, em decisão monocrática, restabelece os efeitos da liminar.

Inconformada, a União requer a suspensão da execução da decisão no Supremo Tribunal Federal (STF), com fundamento no art. 25 da Lei n. 8.038/90, no art. $4^{\circ}$ da Lei n. 8.437/92 e no art. 267 do Regimento Interno do STF (RISTF). A Ministra-relatora Ellen Gracie, na análise da Suspensão Liminar n. 125, em 23 de março de 2007, por considerar a possibilidade de grave ofensa à ordem pública e à economia pública, permite que o Ibama proceda à oitiva das comunidades indígenas

\footnotetext{
${ }_{11}$ Acordo de Cooperação Técnica ECE n. 120/2005 foi questionado pelo Ministério Público Federal, por meio de a Ação Civil Pública (MINISTÉRIO PÚBLICO FEDERAL, 2008).

12 O objeto da ação e a decisão proferida pelo Supremo Tribunal Federal é que determinaram a escolha do presente caso como objeto de estudo da pesquisa.

${ }^{13}$ Em 26 de agosto de 2005, a Procuradoria Geral da República ajuizou a Ação Direta de Inconstitucionalidade n. 3.573 contra o Decreto Legislativo n. 788/2005, que autoriza a implantação da Usina Hidrelétrica de Belo Monte e a realização de Estudos de Impacto Ambiental (EIA) sobre a obra. O Supremo Tribunal Federal (STF), por maioria, não reconheceu a ação direta, sob o argumento que não é o meio adequado para questionar o Decreto Legislativo. Foram vencidos os Senhores Ministros Carlos Ayres Britto (Relator), Joaquim Barbosa, Cezar Peluso e Marco Aurélio. Votou o Presidente, Ministro Nelson Jobim. Redigiu o acórdão o Senhor Ministro Eros Grau. Falaram, pelo Ministério Público Federal, o Dr. Roberto Monteiro Gurgel Santos, Vice-Procurador-Geral da República; pelos interessados, Instituto Socioambiental-ISA, Centro dos Direitos das Populações da Região do Carajás-Fórum Carajás, Coordenação das Organizações Indígenas da Amazônia Brasileira-COIAB e Associação Civil Greenpeace, o Dr. Raimundo Sérgio Barros Leitão; e, pela Advocacia-Geral da União, o Dr. Álvaro Augusto Ribeiro Costa, Advogado-Geral da União. Plenário, 01.12.2005 (SUPREMO TRIBUNAL FEDERAL, 2005).
} 
interessadas e mantém a determinação de realização do EIA e do laudo antropológico pelo governo (SUPREMO TRIBUNAL FEDERAL, 2007).

Cabe ressaltar que, em atenção ao $\int 9^{\circ}$ da Lei n. 8.437/92, com redação incluída pela Medida Provisória n. 2.180-35, de 24 de agosto de 2001, a Suspensão de Liminar deferida pelo Presidente do Tribunal vigora até o trânsito em julgado da decisão de mérito na ação principal, que ainda não ocorreu, no caso da Ação Civil Pública Ambiental n. 2006.39.03.000711-8.

A decisão da Ministra Ellen Gracie na Suspensão Liminar n. 125 permitiu a conclusão dos estudos e, em outubro de 2007, é protocolada na Aneel a Atualização do Inventário Hidrelétrico da Bacia do Rio Xingu: Consolidação dos Estudos Realizados (CENTRAIS ELÉTRICAS BRASILEIRAS, 2007).

Em 2008, o Ministério Público Federal do Pará ajuizou nova a Ação Civil Pública, registrada sob o n. 2008.39.03.000071-9, em desfavor da Eletrobrás, Construções e Comércio Camargo Corrêa S/A., Construtora Andrade Gutierrez S/A. e Construtora Norberto Odebrecht S/A. A ação objetivava a condenação dos demandados pela prática de improbidade administrativa em razão da não realização de licitação para escolher os responsáveis pelo EIA-Rima e a anulação do Acordo de Cooperação Técnica, denominado ECE-120/2005, que objetivava a realização de estudo de viabilidade ambiental da AHE de Belo Monte. $O$ pedido do MPF almejava ainda a imposição de sanção às companhias correspondente à proibição de contratar com o Poder Público, ou, ainda, de participarem da licitação e da contratação do complexo hidrelétrico de Belo Monte.

O Juízo da Vara Federal Única da Subseção Judiciária de Altamira/PA, em 15 de abril de 2008, deferiu a liminar para suspender os efeitos do Acordo de Cooperação Técnica ECE-120/2005 e, por conseguinte, a realização de todo e qualquer ato relacionado ao Aproveitamento Hidrelétrico de Belo Monte, em especial, os estudos de impacto ambiental - EIA/Rima que visavam ao licenciamento do empreendimento. A decisão foi agravada (2008.01.00.021184-4/PA) e a Desembargadora Federal, Relatora Selene Maria de Almeida, do TRF1ª , em 16 de maio de 2008, tornou sem efeito a liminar. ${ }^{14}$

Em maio de 2009, a Eletrobrás, a Camargo Corrêa, Andrade Gutierrez S/A. e Odebrecht divulgam o Relatório de Impacto Ambiental - EIA/Rima, que, quanto aos elementos relacionados à presente pesquisa, ${ }^{15}$ apresentam os possíveis resultados positivos e negativos decorrentes da construção e do funcionamento do AHE Belo Monte.

Em relação aos povos indígenas, a Fundação Nacional do Índio (Funai) determinou que dez comunidades fossem incluídas nos estudos de impacto ambiental, que são: a) Terra Indígena Paquiçamba; b) Terra Indígena Arara da Volta Grande do Xingu; c) Área Indígena Juruna do km 17; d) Terra Indígena Trincheira Bacajá; e) Terra Indígena Arara; f) Terra Indígena Cachoeira Seca; g) Terra

\footnotetext{
14 A Ação Civil Pública teve sentença de improcedência em 31 de janeiro de 2014. A última movimentação processual até o fechamento do presente relatório, em 25 de junho de 2014, indica que o MPF apresentou recurso de apelação (MINISTÉRIO PÚBLICO FEDERAL, 2008).

${ }^{15}$ Em relação ao Rima, destacou-se apenas os pontos relacionados aos povos indígenas. A decisão está relacionada com a Ação Civil Pública n. 2006.39.03.000711-8, que é o objeto de análise da pesquisa.
} 
Indígena Kararaô; h) Terra Indígena Koatinemo; i) Terra Indígena Araweté/Igarapé Ipixuna; j) Terra Indígena Apyterewa (CENTRAIS ELÉTRICAS BRASILEIRAS, 2009, p. 46).

Quadro 1 - Terras Indígenas localizadas na região do AHE Belo Monte

\begin{tabular}{|c|c|c|c|c|}
\hline Terra e Área Indígena & Município & Povo & $\begin{array}{l}\text { Situação } \\
\text { Fundiária }\end{array}$ & \\
\hline TI Paquiçamba & Vitória do Xingu & Juruna & Regularizada & $\begin{array}{l}\text { Homologada e registrada } \\
\text { desde } 1991\end{array}$ \\
\hline $\begin{array}{l}\text { TI Arara da Volta Grande } \\
\text { do Xingu }\end{array}$ & Senador José Porfírio & Arara & Declarada & Declarada em 2008 \\
\hline $\begin{array}{l}\text { Área Indígena Juruna do } \\
\text { km } 17\end{array}$ & Vitória do Xingu & Juruna & Em estudo & Aguardando identificação \\
\hline TI Trincheira Bacajá & $\begin{array}{l}\text { Senador José Porfírio, } \\
\text { Anapu, Altamira e São Félix } \\
\text { do Xingu }\end{array}$ & $\begin{array}{l}\text { Xikrin do } \\
\text { Bacajá }\end{array}$ & Regularizada & $\begin{array}{l}\text { Registrada desde } \\
02 / 10 / 1996\end{array}$ \\
\hline TI Koatinemo & $\begin{array}{l}\text { Altamira e Senador José } \\
\text { Porfírio }\end{array}$ & $\begin{array}{l}\text { Asurini do } \\
\text { Xingu }\end{array}$ & Regularizada & Registrada em 2003 \\
\hline TI Arara & $\begin{array}{l}\text { Brasil Novo, Medicilândia, } \\
\text { Uruará e Altamira }\end{array}$ & Arara & Regularizada & $\begin{array}{l}\text { Homologada em } \\
24 / 12 / 1991\end{array}$ \\
\hline TI Kararaô & Altamira & Kararaô & Regularizada & Registrada em 06/10/1999 \\
\hline TI Cachoeira Seca & Altamira, Placas e Uruará & Arara & Declarada & Declarada \\
\hline $\begin{array}{l}\text { TI Araweté Igarapé } \\
\text { Ipixuna }\end{array}$ & $\begin{array}{l}\text { Altamira, São Félix do Xingu } \\
\text { e Senador José Porfírio }\end{array}$ & Araweté & Regularizada & Registrada \\
\hline TI Apyterewa & São Félix do Xingu & Parakanã & Regularizada & $\begin{array}{l}\text { Homologada em } \\
\text { abril/2007 }\end{array}$ \\
\hline
\end{tabular}

Fonte: Centrais Elétricas Brasileiras (2009, p. 48).

As Terras Indígenas (Tis) de Paquiçamba e Arara da Volta Grande do Xingu e a Área Indígena Juruna do km 17 receberam especial atenção, pois estão dentro da Área de Influência Direta (AID) ${ }^{16}$ que será afetada com a diminuição da vazão do Rio Xingu no trecho de 100 km da Volta Grande do Xingu. Na classificação da Funai para o estudo do AHE de Belo Monte, as três comunidades que estão na AID formam o Grupo 1 e as outras sete o Grupo 2. Foi acrescido ao estudo os índios que moram no município de Altamira e os que vivem às margens do Rio Xingu, no espaço afetado pela construção de Belo Monte (CENTRAIS ELÉTRICAS BRASILEIRAS, 2009, p. 46). ${ }^{17}$

16 O Relatório de Impacto Ambiental (Rima) apresenta duas diferenciações importantes sobre os impactos do AHE Belo Monte, que denominou como Área de Influência Direta e Área Diretamente Afetada. "A Área de Influência Direta (AID) é formada pelos locais onde será construída a barragem, os vertedouros, as casas de força e o futuro reservatório, além dos canteiros, estradas, alojamentos, botafora e aqueles lugares vizinhos às obras que sofrerão efeitos diretos do empreendimento, sejam esses efeitos negativos ou positivos. Já a Área Diretamente Afetada (ADA) é formada somente pelos locais das obras principais (por exemplo, casas de força, barragem, vertedouros) e da infraestrutura de apoio (por exemplo, botafora, empréstimos, travessões), bem como pelos locais de inundação, incluindo: • os reservatórios do Xingu e dos Canais, incluindo os próprios canais e as Áreas de Preservação Permanente (APPs); • o trecho do Xingu localizado entre a barragem principal e a casa de força principal. Esse é o trecho que vai sofrer diminuição da quantidade de água quando a usina entrar em operação; e $\bullet$ o trecho do rio Xingu abaixo da casa de força principal, indo até a região próxima aos bancos de areia onde se reproduzem as tartarugas-da-Amazônia. Os municípios que fazem parte da AID para os estudos socioeconômicos são Altamira, Anapu, Brasil Novo, Senador José Porfírio e Vitória do Xingu. Nessa área estão localizadas as principais estradas da região (Transamazônica, Transassurini e PA-415, que liga as cidades de Altamira e Vitória do Xingu) e os chamados Núcleos de Referência Rural." (CENTRAIS ELÉTRICAS BRASILEIRAS, 2009, p. 58).

${ }^{17}$ A Área Diretamente Afetada do AHE Belo Monte tem uma população total de 19.242 pessoas, sendo que 16.420 vivem na cidade de Altamira e 2.822 vivem no campo. O total de famílias é de 4.362 na cidade, que corresponde a 4.747 imóveis, e 824 no campo, que corresponde a 1.241 imóveis (CENTRAIS ELÉTRICAS BRASILEIRAS, 2009. p. 78). 
Tabela 4 - Grupo 1

\begin{tabular}{lrr}
\hline Terras e Área Indígena & Área Total (ha) & População (hab.) \\
\hline TI Paquiçamba & 4.348 & 81 \\
TI Arara da Volta Grande do Xingu & 25.498 & 107 \\
Área Indígena Juruna do km 17 & 35 & 38 \\
Fonte: Centrais Elétricas Brasileiras (2009, p. 49). & & \\
Tabela 5 - Grupo 2 & Área Total (ha) & População (hab) \\
\hline Terra Indígena & & \\
\hline TI Trincheira Bacajá & 1.650 .939 & \\
TI Koatinemo & 387.834 & \\
TI Arara & 274.010 & 373 \\
TI Kararaô & 330.837 & 39 \\
TI Cachoeira Seca & 734.027 & 81 \\
TI Araweté Igarapé Ipixuna & 940.900 & 398 \\
TI Apyterewa & 773.000 & \\
Fonte: Centrais Elétricas Brasileiras (2009, p. 52). & & \\
\hline
\end{tabular}

Os impactos ambientais para os povos indígenas foram apontados nos estudos realizados para o AHE de Belo Monte. O primeiro é na Etapa dos Estudos e Projetos. O impacto constatado em todos os Territórios e Áreas está na Geração de Expectativas na População Indígena. Em relação aos povos que estão dentro da Área de Influência Direta (AID), aponta-se que os Araras da Volta Grande do Xingu acreditam que há "possibilidade de ocorrer o retorno de parentes índios e o aumento da população de não índios que já vive na terra, gerando conflitos internos e insegurança territorial." (CENTRAIS ELÉTRICAS BRASILEIRAS, 2009, p. 83). Os indígenas de Paquiçamba e Juruna do $\mathrm{km} 17$ acreditam que "pode ocorrer conflitos internos, por causa das opiniões contrárias, entre os indígenas, com relação ao empreendimento." (CENTRAIS ELÉTRICAS BRASILEIRAS, 2009, p. 83).

O segundo momento em que serão sentidos os impactos é na Etapa de Construção de Belo Monte. Nesta fase, na ação de Mobilização e Contratação de Mão de Obra, ocorrerá o Aumento da Pressão sobre as Terras e Áreas Indígenas, que se traduz no aumento de pessoas na região interessadas nas terras e nos recursos naturais, "aumento da disseminação de doenças sexualmente transmissíveis e outras. Além disso, os indígenas ficam mais expostos ao alcoolismo, à prostituição e às drogas." (CENTRAIS ELÉTRICAS BRASILEIRAS, 2009, p. 84-85).

Ainda nesta etapa e ação outro impacto sentido será o relativo ao Aumento das Necessidades por Mercadorias e Serviços, da Oferta de Trabalho e Maior Movimentação da Economia. A contratação de mão de obra pode atrair os jovens indígenas e, por consequência, pode "causar uma quebra de sua organização social, política e cultural." (CENTRAIS ELÉTRICAS BRASILEIRAS, 2009, p. 87-89). Na construção da usina, na ação de Aquisição de Imóveis, a Perda de Imóveis e Benfeitorias com Transferência da População na Área Rural e Perda de Atividades Produtivas pode ampliar a pressão sobre as terras indígenas e seus recursos naturais (CENTRAIS ELÉTRICAS BRASILEIRAS, 2009, p. 90-91). 
$\mathrm{Na}$ ação da Construção de Estradas, Canteiros e Estruturas Principais, a Melhoria dos Acessos vai acarretar impactos na qualidade do ar, no aumento de ruídos e acidentes, pois o fluxo de veículos será ampliado (CENTRAIS ELÉTRICAS BRASILEIRAS, 2009, p. 96-97). Além disso, haverá Mudanças na Paisagem, com a construção da obra (pedreiras, jazidas, escavações, bota-fora, etc.), que impactará, "de forma negativa, a população indígena, porque locais que são referência social e cultural para os índios serão afetados." (CENTRAIS ELÉTRICAS BRASILEIRAS, 2009, p. 97-98).

As obras acarretarão Alterações nas Condições de Acesso pelo Rio Xingu das Comunidades Indígenas à Altamira, que comprometerão as relações econômicas, sociais, culturais e políticas dos indígenas, em especial, das terras de Paquiçamba, Arara da Volta Grande do Xingu e Trincheira Bacajá. Acrescente-se que a alteração do curso do rio acarretará Alteração da Qualidade da Água do Rio Xingu próximo ao Sítio Pimentel e perda de Fonte de Renda e de Sustento para as Populações Indígenas (CENTRAIS ELÉTRICAS BRASILEIRAS, 2009, p. 100-102).

Ainda, na Etapa de Construção de Belo Monte, a ação de Desmobilização da Mão de Obra, a partir do quinto ano do início dos trabalhos, terá um impacto extremamente negativo para os povos indígenas da região. $O$ número de 18 mil trabalhadores diretos e 23 mil trabalhadores indiretos que atuarão no pico da obra cairá para 700 diretos e 2.700 indiretos. Tal fato resultará num grande impacto de Aumento da Pressão sobre as Terras e Áreas Indígenas (CENTRAIS ELÉTRICAS BRASILEIRAS, 2009, p. 84, 105-107). A ação de Desmatamento e Limpeza das Áreas do Reservatório representará para os povos indígenas que estão na Área Diretamente Afetada (ADA) e na Área de Influência Direta (AID) na Retirada de Vegetação, com Perda de Ambientes Naturais e Recursos Extrativistas (CENTRAIS ELÉTRICAS BRASILEIRAS, 2009, p. 84, 107-109).

Na Etapa do Enchimento, que é a fase em que as áreas para o reservatório serão preenchidas e que é o terceiro momento em que serão sentidos os impactos, ocorrerá as Mudanças nas Espécies de Peixes e no Tipo de Pesca e Mudança nas Condições de Navegação. Todas as alterações impactarão no cotidiano das comunidades indígenas, pois ocorrerá mudanças na forma de pescar e de se deslocar na região (CENTRAIS ELÉTRICAS BRASILEIRAS, 2009, p. 111-116, 122-123).

No início de funcionamento da Usina de Belo Monte, que é a Etapa de Operação e o quarto momento em que serão sentidos os impactos, ocorrerá a ação de Liberação do Hidrograma de Vazões Mínimas para o Trecho de Vazão Reduzida. Aqui, os povos indígenas sentirão os impactos da Interrupção da Navegação no Rio nos Períodos de Seca, Prejuízos para a Pesca e para Outras Fontes de Renda e de Sustento. Acrescente-se também o Aumento da Atividade Garimpeira e dos Conflitos com as Populações Indígenas, pois a redução da vazão na época da seca propicia a ampliação desse tipo de atividade econômica na região (CENTRAIS ELÉTRICAS BRASILEIRAS, 2009, p. 129, 131-132).

O Rima apresenta para os impactos negativos decorrentes das quatro etapas ligadas ao Aproveitamento Hidrelétrico de Belo Monte (Estudos e Projetos, Construção de Belo Monte, Enchimento) um conjunto de Planos, Programas e Projetos Ambientais compensatórios, que são de 
responsabilidade da empresa que vai operar o Complexo (CENTRAIS ELÉTRICAS BRASILEIRAS, 2009, p. 138).

Em relação aos povos indígenas as medidas incluem:
* a necessidade de comunicação sobre o empreendimento e suas etapas; a garantia de condições de transporte; * a sustentabilidade econômica das populações indí- genas; * a prevenção de doenças e o desenvolvimento da saúde; * a educação e a capacitação de agentes indígenas ambientais e de saúde; * e a defesa e a promoção das culturas indígenas. (CENTRAIS ELÉTRICAS BRASILEIRAS, 2009, p. 138).

Estas medidas foram contempladas no Plano de Gestão Ambiental, que "tem a função de gerenciar, integrar e acompanhar o desenvolvimento de todos os outros Planos, Programas e Projetos." (CENTRAIS ELÉTRICAS BRASILEIRAS, 2009, p. 141). Compõem o Plano de Gestão Ambiental, como medida mitigatória aos impactos sentidos pelos povos indígenas, o Plano Ambiental de Construção, o Plano de Gestão de Recursos Hídricos, o Plano de Conservação dos Ecossistemas Terrestres, o Plano de Conservação dos Ecossistemas Aquáticos, o Plano de Relacionamento com a População, o Plano de Valorização do Patrimônio, o Plano de Saúde Pública, o Plano de Gerenciamento Integrado da Volta Grande do Xingu, o Plano de Fortalecimento Institucional e Direitos Indígenas, o Plano de Sustentabilidade Econômica da População Indígena, o Plano de Saneamento Básico para as Comunidades Indígenas, o Plano de Readequação do Serviço de Educação para a População Indígena, o Plano de Melhoria das Habitações Indígenas.

Estão vinculados aos Planos o Programa de Saúde e Segurança, o Programa de Monitoramento de Águas Subterrâneas, o Programa de Monitoramento Limnológico e de Qualidade da Água, o Programa de Monitoramento do Microclima Local, o Programa de Desmatamento e Limpeza das Áreas dos Reservatórios, o Programa de Conservação da Fauna Terrestre, o Programa de Orientação e Monitoramento da População Migrante, o Programa de Interação Social e Comunicação, o Programa de Educação Ambiental, o Programa de Vigilância Epidemiológica, Prevenção e Controle de Doenças, o Programa de Monitoramento das Condições de Navegabilidade e das Condições de Vida, o Programa de Fortalecimento das Instituições Indígenas, Programa de Acompanhamento da Implementação dos Planos, Programas e Projetos Ambientais e Etnoecológicos, o Programa de Desenvolvimento de Atividades Produtivas e de Capacitação da População Indígena, o Programa de Garantia de Segurança Alimentar e Nutricional da População Indígena, o Programa de Abastecimento de Água, o Programa de Esgotamento Sanitário e Disposição de Resíduos, o Programa de Segurança Territorial das Terras Indígenas, o Programa de Garantia das Condições de Acessibilidade da População Indígena a Altamira (CENTRAIS ELÉTRICAS BRASILEIRAS, 2009, p. 140-175). 
O conteúdo do Relatório de Impacto Ambiental foi constado internamento no governo federal, dentro do próprio Ibama e Funai, sob o fundamento de que o seu conteúdo não dá suporte consistente em relação aos danos para afirmar se as ações decorrentes irão mitigá-los ou reduzi-los. ${ }^{18}$

Não obstante, em $1^{\circ}$ de fevereiro de 2010, o Ibama concede a Licença Prévia n. 342/2010, que autorizou a Aneel a realizar o leilão público para repassar "o direito de construir, operar a usina e vender energia que será gerada por ela." (CENTRAIS ELÉTRICAS BRASILEIRAS, 2009, p. 10). Em 20 de abril de 2010, Norte Energia S.A. venceu o leilão e ficou com a outorga de concessão por um prazo de 35 anos.

\section{Descrição técnica e fundamentos jurídicos da ação civil pública ambiental objeto da pesquisa}

O Ministério Público Federal do Pará ajuizou Ação Civil Pública Ambiental, com pedido de liminar, na Justiça Federal de Altamira, Pará, contra o Instituto Brasileiro do Meio Ambiente e dos Recursos Naturais Renováveis (Ibama) e a Centrais Elétricas do Norte do Brasil S.A. (Eletronorte).

A medida judicial, registrada sob o n. 2006.39.03.000711-8 e assinada pelos Procuradores da República Marco Antônio Delfino de Almeida e Felício Pontes Júnior, objetivava obstar, no Ibama, o processo de licenciamento do Aproveitamento Hidrelétrico de Belo Monte, no Rio Xingu, e reconhecer a nulidade do Decreto Legislativo n. 788, de 13 de julho de 2005, publicado pelo Congresso Nacional, que autoriza o Poder Executivo a implantar o Aproveitamento Hidrelétrico de Belo Monte depois dos estudos de viabilidade técnica, econômica, ambiental e outros que a Eletrobrás considerasse necessários.

O Ministério Público Federal fundamenta o seu pedido para obstar o licenciamento no Ibama e anular o Decreto Legislativo n. 788/2005 em cinco grandes pontos estratégicos.

p primeiro fundamento jurídico destaca o desrespeito aos preceitos fundamentais contidos no artigo 231, $\ 3^{\circ}$, da Constituição Federal de 1988, pois o aproveitamento dos recursos hídricos, incluídos os potenciais energéticos, a pesquisa e a lavra das riquezas minerais em terras indígenas somente podem ser efetivados com autorização do Congresso Nacional, ouvidas as comunidades afetadas, ficando-lhes assegurada participação nos resultados da lavra (MINISTÉRIO PÚBLICO FEDERAL, 2006, p. 3-6, 8-13).

Ocorre que os povos indígenas afetados não foram consultados nos termos da Constituição Federal e da Convenção n. 169 da Organização Internacional do Trabalho (OIT), que foi ratificada pelo Brasil, em 19 de junho de 2002, por meio do Decreto Legislativo n. 142, e promulgada

18 O Tribunal Regional Federal de $1^{\circ}$ Região acatou, em parte, a apelação do Ministério Público Federal no processo n. 0025999-75.2010.4.01.3900/PA. A decisão determinou a anulação da licença prévia n. 342/2010 do Ibama, pois foi dada com base em estudo ambiental impreciso. Dessa forma, o EIA/Rima deve ser readequado (TRIBUNAL REGIONAL FEDERAL DA $1^{a}$ REGIÃO, 2014). 
pelo Decreto n. 5.051, de 19 de abril de 2004. O Congresso Nacional deveria ter consultado as comunidades afetadas antes de promulgar o Decreto Legislativo n. 788/2005 (MINISTÉRIO PÚBLICO FEDERAL, 2006, p. 3-6, 8-13).

O segundo fundamento jurídico está relacionado com os impactos a serem experimentados pelas populações indígenas. As etapas de estudos e projetos, construção da usina, enchimento do reservatório e operação de Belo Monte acarretaram e acarretarão uma série de impactos negativos na organização social, política, econômica e cultural dos povos indígenas. Os conflitos, as pressões sobre as terras e recursos naturais, as limitações para a caça e a pesca, a restrição no deslocamento e a alteração da geografia do local podem conduzir à extinção dos grupos étnicos afetados (MINISTÉRIO PÚBLICO FEDERAL, 2006, p. 6-8).

terceiro fundamento jurídico aponta o atentado ao devido processo legislativo. $\bigcirc$ Decreto Legislativo n. 788/2005 foi aprovado na Câmara de Deputados e, ao ser analisado no Senado Federal, foi alterado sem o devido retorno à casa de origem. O Ministério Público Federal argumenta que a emenda do Senado - que incluiu a participação do Estado do Pará nos estudos a serem realizados - tem índole modificativa. Tal fato exigiria o retorno do projeto à Câmara, conforme consta do art. 123 do Regimento Interno da Câmara dos Deputados (RICD) (MINISTÉRIO PÚBLICO FEDERAL, 2006, p. 13-14).

O quarto fundamento jurídico expõe que não existe Lei Complementar que regule a forma de exploração dos recursos hídricos em área indígena, conforme determina o art. $₫ 6^{\circ}$, do art. 231, da Constituição Federal da Constituição Federal. A ausência de norma regulamentadora, combinado com o disposto nos $\iint 1^{\circ}$ e $3^{\circ}$ do mesmo artigo da Carta Cidadã, é um óbice intransponível para o desejado AHE de Belo Monte. Acrescenta, ainda, o Ministério Público Federal que o Congresso Nacional editou o inconstitucional Decreto Legislativo n. 788/2005, sem especificar como ocorreria o retorno financeiro às comunidades indígenas afetadas pela construção do empreendimento, conforme dispõe o $₫ 3^{\circ}$ acima mencionado (MINISTÉRIO PÚBLICO FEDERAL, 2006, p. 14-16).

O quinto fundamento jurídico aponta que há inconstitucionalidade no processo de licenciamento ambiental. Dois argumentos conduzem a afirmação do Ministério Público Federal e ambos estão relacionados à fase de elaboração do Termo de Referência do Estudo de Impacto Ambiental. O primeiro indica que há ausência de sustentação constitucional para a realização dos estudos, pois não houve oitiva prévia pelo Congresso Nacional dos povos indígenas que serão afetados pela usina de Belo Monte, conforme determina a Constituição Federal. $\bigcirc$ segundo argumento aponta que as duas reuniões para embasar a elaboração do Termo, previstas para o dia 30 e 31 de março de 2006, em Altamira e Vitória do Xingu, não tiveram ampla divulgação para a sociedade e também não foram comunicadas aos povos indígenas que seriam afetados (MINISTÉRIO PÚBLICO FEDERAL, 2006, p. 16-18).

A conclusão do Ministério Público Federal é que "à luz de uma interpretação principiológica do Texto Constitucional, mormente dos arts. 49, XVI e 231, $\mathbb{S} 3^{\circ}$, tanto a autorização quanto à 
oitiva das comunidades indígenas estão na esfera de atribuições exclusivas - daí porque indelegáveis - do Congresso Nacional." (MINISTÉRIO PÚBLICO FEDERAL, 2006, p. 17-18).

Em outras palavras, o Poder Legislativo não poderia delegar para o Poder Executivo a competência para autorizar, em terras indígenas, a exploração e o aproveitamento de recursos hídricos e a pesquisa e lavra de riquezas minerais e, também, a oitiva das comunidades indígenas.

A conexão dos cinco grandes pontos estratégicos suscitados na Ação Civil Pública resultou no pedido de "condenação do IBAMA em obrigação de não-fazer, consistente na proibição de adotar atos administrativos referentes ao licenciamento ambiental da Usina Hidrelétrica de Belo Monte." (MINISTÉRIO PÚBLICO FEDERAL, 2006, p. 19).

\section{Conteúdo das decisões proferidas pela Justiça Federal na Ação Civil Pública objeto da pesquisa}

A Ação Civil Pública Ambiental n. 2006.39.03.000711-8 teve seu pedido de liminar deferido pela Subseção Judiciária Federal de Altamira para, inaudita altera pars, determinar a suspensão de qualquer procedimento do Ibama e da Eletronorte na condução do licenciamento da Usina Hidrelétrica de Belo Monte, especificamente às audiências previstas para o dia 30 e 31 de março de 2006. A liminar fixou, ainda, multa pelo descumprimento da decisão no valor de um milhão de reais e responsabilidade solidária dos administradores responsáveis em caso de inobservância da ordem, sem prejuízo da responsabilidade criminal (PARÁ, 2007, p. 4).

A liminar foi revogada pelo Juiz Federal Titular da Subseção Judiciária de Altamira, Pará, o MM. Herculano Martins Nacif, para que fosse retirado:

qualquer óbice judicial à prática dos procedimentos a serem empreendidos pela União, pela Eletrobrás, pela Eletronorte e, especialmente, pelo IBAMA, este na condução do licenciamento da Usina Hidrelétrica de Belo Monte, inclusive a realização de estudos, consultas públicas, audiências públicas, enfim, tudo que seja necessário a possibilitar a conclusão final da autarquia ambiental quanto ao licenciamento, ou não, da obra, ficando assegurado o pleno exercício do seu poder de polícia, com integral e estrita observância do Decreto Legislativo n. ${ }^{\circ} 788 / 2005$, do Congresso Nacional. (PARÁ, 2007, p. 4).

O Juiz Federal também aceitou a inclusão da Eletrobrás no polo passivo da ação, pois a empresa tinha a competência para abertura do processo de licenciamento ambiental no Ibama, e a participação da União como assistente simples da Eletronorte (PARÁ, 2007, p. 4).

O Ministério Público Federal do Pará interpôs o recurso de Agravo de Instrumento, registrado sob o n. 2006. 01.00.017736-8/PA, para o Tribunal Regional Federal da $1^{a}$ Região. A Desembargadora Federal, Relatora Selene Maria de Almeida, entendeu que os elementos socioeconômicos que envolvem o AHE Belo Monte são relevantes, mas que processos e procedimentos definidos no ordenamento jurídico brasileiro devem ser observados de forma plena sob pena de inconstitucionalidade (TRIBUNAL REGIONAL FEDERAL DA $1^{\text {a }}$ REGIÃO, 2006). 
Como base de sua afirmação, a Desembargadora Federal Relatora apontou: que há dúvida sobre eventuais vícios no processo legislativo que resultou no Decreto Legislativo n. 788/2005; que não se tem clareza do momento que se deve ouvir as comunidades indígenas afetadas pelo AHE Belo Monte, conforme o disposto no $\int 3^{\circ}$ do art. 231 da Constituição Federal. Dessa forma, é razoável que a oitiva ocorra antes da edição da autorização legislativa; que o art. $6^{\circ}$ da Convenção n. 169 da OIT, promulgada pelo Decreto n. 5.051, de 19 de abril de 2004, determina a consulta dos povos interessados diretamente. Os argumentos apresentados foram o alicerce para o deferimento, em 24 de maio de 2006, do pedido formulado pelo Ministério Público Federal no recurso de Agravo de Instrumento e os procedimentos relativos ao licenciamento foram novamente suspensos (TRIBUNAL REGIONAL FEDERAL DA $1^{\text {a }}$ REGIÃO, 2006).

A União requer a suspensão da execução da decisão para o Supremo Tribunal Federal e a Ministra-relatora Ellen Gracie, em 23 de março de 2007, por entender que há grave ofensa à ordem pública e à economia pública, concede o efeito. Neste momento os procedimentos ligados ao EIA/ Rima e o licenciamento estão autorizados. ${ }^{19}$

A suspensão de segurança deferida pelo STF tem os seus efeitos garantidos até o transito em julgado do processo. Nesse sentido, o trâmite da ação transcorreu nos limites definidos pelo Código de Processo Civil. O Juiz Federal Herculano Martins Nacif proferiu sentença de improcedência aos pedidos formulados pelo Ministério Público Federal na Ação Civil Pública Ambiental.

O magistrado compreendeu, em síntese, que o Decreto Legislativo n. 788/2005 é constitucional e que há inexistência de vício formal. A norma seria a expressão da vontade do povo traduzida pelo Congresso Nacional, o que dificulta a sua censura. É nos Senadores e Deputados "e no seu entendimento ideológico que as populações depositam seus votos de confiança. São eles os mais legítimos representantes do sentimento geral das pessoas que representam." (PARÁ, 2007, p. 15). Além disso, os estudos mencionados na norma são condições de validade para a autorização a ser concedida para o aproveitamento dos recursos hídricos, que inclui o potencial energético. $\bigcirc$ que precisa de autorização é o aproveitamento. Os estudos ou reuniões não necessitam (PARÁ, 2007, p. 15-16). No que diz respeito ao vício no processo legislativo pelo acréscimo de redação ocorrido no Senado e o não retorno da norma à Câmara, o magistrado entende que inexistiu prejuízo. "Em deferência ao princípio da razoabilidade, não se pode eivar de inconstitucionalidade, ou mesmo de ilegalidade, nenhum acréscimo textual que não traga prejuízos para o interesse público." (PARÁ, 2007, p. 24).

Em relação ao momento da oitiva das comunidades indígenas, o magistrado compreende que não é oportuna antes dos estudos de viabilidade do empreendimento e do estudo antropológico, pois, do contrário, ocorreriam manifestações casuísticas sem amparo técnico de pessoas que não saberiam se realmente seria afetadas (PARÁ, 2007, p. 16-21). Além disso, a oitiva dos povos

19 O conteúdo da Suspensão de Segurança será aprofundado em seção específica do relatório (SUPREMO TRIBUNAL FEDERAL, 2007). 
indígenas pode ser delegada do Congresso Nacional para o Poder Executivo sem que se traduza em inconstitucionalidade. O que é de competência exclusiva do parlamento e, "portanto, indelegável, é a autorização legislativa, tão somente." (PARÁ, 2007, p. 24-25).

O magistrado, na sentença, ainda destaca apontamentos jurisprudenciais sobre a importância "de ser prestigiada a questão energética em precedente relativo à Usina Binacional de Itaipu" e sobre a "construção de hidrelétricas em terras indígenas". ${ }^{20}$

Independentemente dos impactos a serem sofridos pelos povos indígenas, a decisão entende que há desnecessidade de Lei Complementar para a exploração de recursos energéticos em área indígena. $O$ entendimento está centrado na ideia de que objetivos fundamentais da República Federativa do Brasil, numa leitura sistêmica da Constituição Federal, combinados com o princípio do interesse público, dão guarida para uma exceção que dispensaria ou supriria a necessidade de publicação de Lei Complementar expressamente prevista no \ $6^{\circ}$ do art. 231 da Carta Cidadã (PARÁ, 2007, p. 29-31). Ademais, questões estratégicas nacionais, como a necessidade de independência brasileira do gás oriundo da Bolívia e necessidade de autossuficiência para a produção de energia justificam a necessidade de se "plantar agora para colher depois" (PARÁ, 2007, p. 31-32).

Os apontamentos realizados na sentença fundamentam uma visão da importância do empreendimento como um sinônimo de desenvolvimento nacional e, por consequência, da necessidade de se integrar ou incluir os "nossos irmãos indígenas" neste projeto para que se garanta o "direito à dignidade da pessoa humana." (PARÁ, 2007, p. 41-47). Ambas posições sustentam a improcedência total da Ação Civil Pública Ambiental.

O Ministério Público Federal interpôs recurso de apelação para o Tribunal Regional Federal da $1^{\text {a }}$ Região, que, por maioria, negou provimento à apelação e à remessa oficial. A Desembargadora Federal Relatora Selene Maria de Almeida, vencida no julgamento, apresentou elementos "extralegais" (TRIBUNAL REGIONAL FEDERAL DA 1ª REGIÃO, 2011) que ensejam o conflito e sustentou que o recurso deveria ser acolhido com base em cinco argumentos jurídicos centrais.

Em primeiro, há vício formal do Decreto Legislativo n. 788/2005, "por haver sido modificado no Senado sem retorno para apreciação pela Câmara dos Deputados." (TRIBUNAL REGIONAL FEDERAL DA $1^{a}$ REGIÃO, 2011, p. 14-15). Em segundo, a invisibilidade social e política dos ribeirinhos impede que se tenha claro qual será o tratamento legal dado pelo governo quanto à terra, em especial, pelo fato das respectivas populações tradicionais não terem, em sua grande maioria, o título de propriedade dos imóveis (TRIBUNAL REGIONAL FEDERAL DA 1ª REGIÃO, 2011, p. 15-18). Em terceiro, impossibilidade de delegação de competência do Congresso Nacional para oitiva das comunidades indígenas. A competência é exclusiva do parlamento e não pode ser repassada para o

\footnotetext{
${ }^{20}$ Da reflexão realizada na decisão a quo neste ponto chama a atenção a afirmação do juiz de que "a UHE Belo Monte não será construída em terras indígenas, mas em área que influenciará diretamente somente a Aldeia Indígena Paquiçamba." Nota-se, contudo, que os diversos estudos realizados pelo governo desde a década de 1970 indicam que, ao menos, as comunidades indígenas de Paquiçamba, Arara da Volta Grande do Xingu e Juruna do km 17 seriam diretamente atingidas pelo empreendimento (PARÁ, 2007. p. 27-29).
} 
executivo (TRIBUNAL REGIONAL FEDERAL DA $1^{\text {a }}$ REGIÃO, 2011, p. 15). Em quarto, o momento da oitiva dos povos indígenas é prévia. "Sendo a oitiva das comunidades afetadas um antecedente condicionante à autorização, é inválida a autorização do DL 788/2005." (TRIBUNAL REGIONAL FEDERAL DA $1^{\text {a }}$ REGIÃO, 2011, p. 20). Em quinto, a consulta prévia deve obedecer ao disposto na Convenção n. 169 da Organização Internacional do Trabalho (OIT), pois o Brasil é signatário e se comprometeu internacionalmente a cumprir com o seu conteúdo (TRIBUNAL REGIONAL FEDERAL DA $1^{\text {a }}$ REGIÃO, 2011, p. 21-30).

A combinação dos argumentos apresentados ensejaram a decisão vencida de "reformar a sentença e considerar inválido o Decreto Legislativo n. 788/2005, em interpretação conforme a Constituição e violar os artigos $6^{\circ}$ e $7^{\circ}$ da Convenção 169 da OIT tornando sem efeito o licenciamento ambiental do Aproveitamento Hidrelétrico de Belo Monte - AHE Belo Monte." (TRIBUNAL REGIONAL FEDERAL DA $1^{\text {a }}$ REGIÃO, 2011, p. 31).

A decisão da Quinta Turma do Tribunal Regional Federal da $1^{\text {a }}$ Região que, por maioria, vencida a relatora, negou provimento ao recurso de apelação do Ministério Público Federal e à remessa oficial, orienta-se pela decisão do Supremo Tribunal Federal, na análise da Suspensão de Liminar n. 125. Entenderam os Desembargadores Federais, Fagundes de Deus e Maria do Carmo Cardoso, que a Corte Constitucional já declarou que não há vício formal na elaboração e no conteúdo do Decreto Legislativo n. 788/2005. Dessa forma,

é imprescindível reconhecer a preexistência de fatos e o transcurso de etapas que, sob qualquer ponto de vista, tornam irreversível a continuidade do empreendimento, porquanto houve: vontade política estatal expressa de aproveitar o potencial hidroelétrico de Belo Monte; vontade do Conselho Nacional de Política Energética em materializar a usina de Belo Monte; decisão do parlamento "pertinente, legítima e oportuna"; decisões variadas da administração para implementar o AHE Belo Monte; "respaldo do Poder Judiciário, consubstanciado em pronunciamentos do STF e desta Corte, que asseguraram a continuidade das etapas subsequentes do empreendimento. (TRIBUNAL REGIONAL FEDERAL DA $1^{\text {a }}$ REGIÃ̃O, 2011, p. 2-3).

Acrescenta-se ainda que o $\int 3^{\circ}$ do art. 231 da Constituição Federal não diz que a oitiva das comunidades indígenas deve ser antes da autorização do Congresso Nacional e, além disso, a melhor entidade para realizar a consulta às "comunidades tribais pode e deve ser" a Fundação Nacional do Índio (Funai). A autorização do parlamento para realização destas consultas "Deve anteceder, inclusive, aos estudos de impacto ambiental, a fim de evitar dispêndios indevidos de recursos públicos." Como foram realizadas várias consultas às comunidades indígenas ao longo dos estudos de impacto ambiental não é possível afirmar que houve ofensa à Convenção n. 169 da OIT, em especial, porque a norma não estabelece que "a consulta aos povos indígenas deva ser prévia à autorização do Congresso Nacional." Em relação ao disposto no $\int 6^{\circ}$ do art. 231 da Constituição Federal, exige-se a publicação de Lei Complementar apenas para a exploração das riquezas naturais do solo, dos rios e 
dos lagos existentes em terras ocupadas pelos índios. A exigência não se aplica ao aproveitamento de recursos hídricos (TRIBUNAL REGIONAL FEDERAL DA 1ª REGIÃO, 2011, p. 3-4).

O Ministério Público Federal apresentou recurso de embargos de declaração contra o acórdão da apelação julgado pela Quinta Turma do Tribunal Regional Federal da $1^{\text {a }}$ Região, afirmando que houve omissão na decisão em relação às normas da Convenção n. 169 da OIT. O julgado acabou

resolvendo a questão "em bloco" e negando a incidência do tratado, de modo genérico, impondo-se o expresso pronunciamento da Turma julgadora acerca da observância, no caso, dos arts. $6^{\circ}$, I, a, b e c, 2; $7^{\circ}, 1,2$, e, 4; 14, 2 e 15, 1, 2 da referida Convenção, bem assim, sobre a "incidência, no caso, do Decreto Legislativo n. ${ }^{\circ}$ 143/2002, que é norma por cujo meio o referido tratado internacional foi incorporado e passou a ter eficácia no Brasil" - fls. 1418/1424. (TRIBUNAL REGIONAL FEDERAL DA 1ª REGIÃO, 2012, p. 4-5).

O Desembargador Federal, Relator dos embargos de declaração, Souza Prudente, reconhece que houve omissão no julgado da apelação. O Desembargador aponta que a Convenção n. 169 da OIT foi equiparada à norma constitucional, em atenção ao $₫ 3^{\circ}$ do art. $5^{\circ}$ da Constituição Federal, acrescentado pela Emenda Constitucional n. 45, de 30 de dezembro de 2004, e o sentido do seu conteúdo foi atribuído pelo Supremo Tribunal Federal no julgamento do Habeas Corpus n. 87585 - Pleno, de 25 de junho de 2009. Portanto, o art. 15 da Convenção n. 169 da OIT deve ser observado, pois prevê que a consulta dos povos interessados deve ocorrer antes de se "empreender ou se autorizar qualquer programa de prospecção ou exploração dos recursos existentes nas suas terras." (BRASIL, 2004; TRIBUNAL REGIONAL FEDERAL DA $1^{\text {a }}$ REGIÃO, 2012, p. 35-36).

Ademais, a decisão da Ministra Ellen Gracie, do Supremo Tribunal Federal, na Suspensão Liminar n. 125, não declarou expressamente a constitucionalidade do Decreto Legislativo n. 788/2005, conforme afirmação contida na sentença e no acórdão vencedor da apelação. Nos termos do art. 21, incisos IV e V, e art. 22 do Regimento Interno do STF combinado com os arts. 10, 11 e 12 da Lei n. 9.868, de 10 de novembro de 1999, "qualquer decisão monocrática de natureza cautelar tomada em ação direta de controle de constitucionalidade deverá partir da maioria absoluta dos membros do Tribunal da Suprema Corte [...]” (TRIBUNAL REGIONAL FEDERAL DA 1ª REGIÃO, 2012, p. 41).

A constatação se torna relevante à medida que os julgadores de primeiro e segundo grau, do acórdão vencedor, entenderam que a decisão do STF teria colocado "uma pá de cal quanto à constitucionalidade do Decreto Legislativo n. 788/2005, portanto, não há mais o que se discutir sobre essa questão, diz o mesmo voto vencedor." (TRIBUNAL REGIONAL FEDERAL DA $1^{a}$ REGIÃO, 2012, p. 43). Esta posição, segundo o Desembargador Federal Souza Prudente, não tem espaço quando se realiza a leitura dos diplomas legais que regulam o tema.

O acórdão dos embargos de declaração ainda ressalta que a forma que foi conduzida a publicação do Decreto n. 788/2005, no Congresso Nacional, não condiz com os ditames de um Estado Democrático de Direito. A velocidade que foi imprimida no trâmite e aprovação da norma que autoriza o aproveitamento do potencial hidrelétrico de Belo Monte, antes da oitiva dos povos 
afetados, remonta a "um ato de ditadura, um ato autoritário, um ato que imponha às comunidades indígenas um regime de força, como assim repudia o art. $3^{\circ}$, item II, da Convenção n. 169-OIT [...]" (TRIBUNAL REGIONAL FEDERAL DA $1^{a}$ REGIÃO, 2012, p. 52). A autorização antes da oitiva e da análise dos estudos de impacto ambiental pelas comunidades atingidas se traduz em um "estudo póstumo às consultas necessárias à participação das comunidades indígenas" (grifo do autor). A Carta Cidadã "consagrou um estudo prévio de impacto ambiental (CF, art. 225, \ $1^{\circ}$, IV), e o governo federal quer implantar um estudo póstumo de impacto ambiental, na espécie, assim, anulando os direitos fundamentais dessas comunidades indígenas." (TRIBUNAL REGIONAL FEDERAL DA $1^{\text {a }}$ REGIÃO, 2012, p. 54). Os princípios fundamentais e os direitos fundamentais da Constituição Federal de 1988 declaram que vivemos numa sociedade multicultural que deve garantir aos povos que tem uma relação de pertencimento com a natureza "o mínimo existencial socioambiental (ou ecológico) e a tutela integrada do ambiente e dos direitos sociais como premissa do desenvolvimento sustentável [...]" (TRIBUNAL REGIONAL FEDERAL DA 1ª REGIÃO, 2012, p. 58).

Os fatos que circundam e que integram o objeto da ação exigem do Poder Judiciário, segundo o Desembargador Federal Souza Prudente, uma prestação jurisdicional inibitória de controle das políticas públicas que apresentem risco ambiental. A medida é um mecanismo de concretização dos princípios da precaução, da prevenção e da proibição do retrocesso ecológico, que garantem, "inclusive, o mínimo existencial-ecológico dos povos indígenas atingidos diretamente e indiretamente em seu patrimônio de natureza material e imaterial (CF, art. 216, caput, incisos I e II) pelo Programa de Aceleração Econômica do Poder Executivo Federal." (TRIBUNAL REGIONAL FEDERAL DA $1^{a}$ REGIÃO, 2012, p. 62-63).

A Desembargadora Federal Selene de Almeida acrescenta em seu voto vogal que o governo federal tem uma política moderna de administração que, por meio do Plano Decenal de Energia Elétrica e do Plano de Aceleração do Crescimento, 2011/2020, planeja cenários e ações de médio e longo prazo para o setor. Sabendo os caminhos a serem trilhados para o futuro e sabendo que todos terão impactos socioambientais, a Desembargadora questiona porque o governo não consulta previamente o "gênero humano" que sofrerá diretamente com os efeitos. Não há necessidade de se produzir os mesmos erros com os povos indígenas que o Brasil comete nos últimos 500 anos (TRIBUNAL REGIONAL FEDERAL DA $1^{\text {a }}$ REGIÃO, 2012, p. 2-5).

O Desembargador Federal João Batista Moreira, no seu voto vogal, afirma que não existem normas programáticas na Constituição Federal. Todos os dispositivos são de eficácia plena e imediata. Segundo o Desembargador,

Já dissera Marx, a propósito da Constituição da República Francesa, que é um "ardil" a promessa de liberdade total e a garantia dos mais belos princípios, se se deixa sua aplicação, os detalhes, para decisão da legislação posterior (informação de Alexi, no livro Teoria dos Direitos Fundamentais, p. 325, tradução para o português, coincidentemente, de Virgílio Afonso da Silva). TRIBUNAL REGIONAL FEDERAL DA $1^{\text {a }}$ REGIÃO, 2012, p. 1-3). 
Portanto, não há como afirmar que a oitiva dos indígenas, prevista no $\int 3^{\circ}$ do art. 231 da Constituição Federal, necessite de lei por ser uma norma de caráter programático, pois, dessa forma, a exploração dos recursos minerais e hídricos nas terras desses povos também necessitaria (TRIBUNAL REGIONAL FEDERAL DA $1^{\text {a }}$ REGIÃO, 2012, p. 1-3). O Desembargador, ao final da decisão, aponta uma desesperança na manutenção do julgamento, "haja vista a suspensão de segurança, considerando, especialmente, o fato consumado, o adiantado na execução do projeto." Contudo, o julgado terá um resultado didático, em especial, pelo processo de expansão de projetos do presente tipo para a Amazônia (TRIBUNAL REGIONAL FEDERAL DA $1^{\text {a }}$ REGIÃO, 2012, p. 7).

Após a manifestação dos três Desembargadores Federais, foram atribuídos efeitos infringentes aos embargos de declaração para sanar a omissão existente no julgamento da apelação e foi reformada a sentença proferida no processo. No acórdão foi julgado procedente o pedido formulado pelo Ministério Público Federal na ação civil pública para

coibir o Instituto Brasileiro de Meio Ambiente e dos Recursos Naturais Renováveis - IBAMA de praticar qualquer ato administrativo, e tornar insubsistentes aqueles já praticados, referentes ao licenciamento ambiental da Usina Hidrelétrica de Belo Monte, no Estado do Pará, em decorrência da invalidade material do Decreto Legislativo n. ${ }^{\circ} 788 / 2005$, por violação à norma do art. 231, $\int 3^{\circ}$, da Constituição Federal, c/c arts. $3^{\circ}$, item $1,4^{\circ}$, itens 1 e 2, item 1 , alíneas $a, b$, e c, e $2 ; 7^{\circ}$, itens 1,2 e $4 ; 13$, item $1 ; 14$, item 1 ; e 15, itens 1 e 2 da referida Convenção n. ${ }^{\circ}$ 169/OIT. (TRIBUNAL REGIONAL FEDERAL DA $1^{\text {a }}$ REGIÃO, 2012, p. 62-63).

A União e o Ibama apresentaram Reclamação Constitucional com pedido liminar para o STF contra o acórdão dos Embargos de Declaração proferido na Apelação Cível n. 2006.39.03.0007118. Os reclamantes apontaram que a decisão dos embargos impede o Ibama de praticar atos relacionados ao licenciamento ambiental e que tal entendimento contraria a Suspensão de Liminar n. 125 do STF.

O Ministro Ayres Britto, em 27 de agosto de 2012, deferiu a liminar para suspender os efeitos do acórdão dos Embargos de Declaração da Quinta Turma do TRF $1^{a}$ Região e permitir que o Ibama pratique os atos relacionados ao licenciamento ambiental (SUPREMO TRIBUNAL FEDERAL, 2012).

\section{Conteúdo da suspensão de segurança n. 125, do Supremo Tribunal Federal, que incide na ação civil pública objeto da pesquisa}

A Suspensão de Liminar n. 125 do Supremo Tribunal Federal merece especial atenção na reflexão e análise das decisões político-jurídicas relacionadas ao Aproveitamento Hidrelétrico da Usina de Belo Monte. O conteúdo da medida, redigida pela Ministra-Relatora Ellen Gracie, em 16 de março de 2007, é a primeira manifestação formal da Corte Constitucional do Brasil que ratifica a eficácia do Decreto Legislativo n. 788/2005 do Parlamento e desobstrui as ações do Poder Executivo direcionadas ao aproveitamento do empreendimento. 
Após a decisão, os estudos de impacto ambiental, o leilão do empreendimento e o início das obras se materializaram. Em atenção às normas que regulam a Suspensão de Liminar no ordenamento jurídico brasileiro, o seu deferimento garante os efeitos do seu conteúdo até o trânsito em julgado da ação judicial, que pode levar mais tempo do que a própria construção da obra. Em outras palavras, o seu conteúdo evoca a ideia do "fato consumado", pois, se a última decisão do processo revoga o seu conteúdo, a obra já está em fase adiantada ou concluída.

Nesse contexto, o detalhamento da decisão do STF ganha importância diferenciada e justifica o motivo pelo qual toda a Ação Civil Pública Ambiental n. 2006.39.03.000711-8 é objetivo da pesquisa. $\bigcirc$ conteúdo da Suspensão de Liminar n. 125 do STF não se limita à presente ação. Como observado, ela também tem projeções para o futuro em outros casos de igual complexidade e que serão judicializados.

Especificamente na Ação Civil Pública o pedido de suspensão da execução de liminar foi utilizado pela União depois que a Desembargadora-Federal Selene Maria de Almeida deferiu a liminar na análise do Agravo de Instrumento n. 2006.01.00.017736-8/PA, que tramitava no Tribunal Regional Federal da $1^{\text {a }}$ Região.

O pedido, com fundamento no art. 25 da Lei n. 8.038/90, no $4^{\circ}$ da Lei n. 8.437/92 e no art. 267 do RISTF, retoma todas as fases do processo até a interposição do Agravo de Instrumento pelo Ministério Público Federal. Diante dos fatos apresentados, a Ministra Ellen Gracie destaca os principais argumentos da União e do Ministério Público Federal na lide e reconhece que a alegação de inconstitucionalidade do Decreto Legislativo n. 788/2005 evidencia a existência de matéria a ser enfrentada pelo STF.

A Ministra, citando julgados do STF, afirma que o enfrentamento da inconstitucionalidade ou não do Decreto Legislativo exigiria um juízo mínimo de deliberação de mérito da sua parte, que foi realizado por blocos argumentativos. Em primeiro, o Decreto Legislativo n. 788/2005 foi aprovado pelo Congresso Nacional dentro dos marcos constitucionais, ou seja, "no exercício legítimo de sua competência soberana e exclusiva (art. 49, XVI, da Constituição da República)." A norma não foi revogada, o que significa que está em vigor e tem plena eficácia (SUPREMO TRIBUNAL FEDERAL, 2007).

Em segundo, os arts. $1^{\circ}$ e $2^{\circ}$ do Decreto Legislativo n. 788/2005 têm caráter programático quando autorizam o governo a aproveitar o potencial hidrelétrico de Belo Monte após os estudos de impacto necessários. Impedir o Executivo de consultar as comunidades indígenas com a concessão de liminar no Agravo de Instrumento era prematuro e ofensivo à ordem administrativa. Não obstante, a via da suspensão de execução de decisão impede que se analise se a consulta tem caráter político ou técnico (SUPREMO TRIBUNAL FEDERAL, 2007).

Em terceiro, os estudos previstos no Decreto Legislativo n. 788/2005 são "determinantes para viabilizar o empreendimento e, se aprovados pelos órgãos competentes, permitirão que o Executivo adote as medidas previstas em lei objetivando a implantação do aproveitamento hidroelétrico 
em apreço." (SUPREMO TRIBUNAL FEDERAL, 2007). Nesse sentido, o Ibama não pode ser impedido de consultar as comunidades indígenas e não se deve obstar os estudos antropológicos, que tem por escopo apontar quem será afetado com o empreendimento.

Em quarto, o empreendimento é estratégico para a política energética nacional. A inexecução da obra "exigiria a construção de dezesseis outras usinas na região com ampliação em quatorze vezes da área inundada, o que agravaria o impacto ambiental e os vultosos aportes financeiros a serem despendidos pela União." (SUPREMO TRIBUNAL FEDERAL, 2007).

Em quinto, a decisão do Poder Judiciário de vedar que o Ibama realize consulta às comunidades e, por consequência, de interferir "no cronograma governamental de planejamento estratégico do setor elétrico do país", é um controle sobre conteúdo de política pública do Executivo e invade a "esfera de discricionariedade administrativa." (SUPREMO TRIBUNAL FEDERAL, 2007).

Em sexto, não pode ser analisada na suspensão liminar - mas só instrução de mérito da ação - a tese apresentada pelo Ministério Público Federal de que ocorreu ofensa ao devido processo legislativo na elaboração do Decreto n. 788/2005 e de que inexiste a lei complementar prevista no \ $6^{\circ}$ do art. 231 da Constituição. Tal análise também será feita na "via administrativa, mediante a realização dos estudos de viabilidade técnica, econômica, ambiental e outros que forem necessários à implantação do 'Aproveitamento Hidroelétrico Belo Monte', conforme prevê o Decreto Legislativo 788/2005." (SUPREMO TRIBUNAL FEDERAL, 2007).

A combinação dos argumentos jurídicos apresentados pela Ministra-Relatora Ellen Gracie resultou no entendimento de que o acórdão do Agravo de Instrumento era "ofensivo à ordem pública, aqui entendida no contexto da ordem administrativa, e à economia pública." Portanto, foi reconhecida a eficácia do Decreto Legislativo n. 788/2005 e foi deferido o pedido de suspensão liminar para permitir que o Ibama realizasse a oitiva das comunidades indígenas, os estudos de impacto ambiental e o laudo antropológico (SUPREMO TRIBUNAL FEDERAL, 2007).

\section{Considerações finais}

O estudo apresentado demonstra que há uma supremacia da ordem econômica pública sobre direitos fundamentais dos povos indígenas, que, objetivamente, já foram afetados pela megaobra da Usina Hidrelétrica de Belo Monte.

A Constituição Federal é expressa em afirmar que é vedada a remoção dos grupos indígenas de suas terras, salvo, ad referendum do Congresso Nacional, em caso de catástrofe ou epidemia que coloque em risco sua população, ou no interesse da soberania do País, após deliberação do parlamento, garantido, em qualquer hipótese, o retorno imediato logo que cesse o risco.

No entanto, a megaobra permitiu a remoção de grupos indígenas sob o argumento do interesse da soberania nacional, ordem pública e, em especial, economia pública, sem garantir o direito constitucional do retorno às terras para garantia da reprodução física e cultural, seus usos, costumes 
e tradições. Em outras palavras, a remoção foi realizada contrariando o próprio conteúdo da regra constitucional que impede a remoção das etnias.

No que se refere ao processo legislativo, o Decreto n. 788/2005, que autorizou a construção da UHE de Belo Monte, em evidente inconstitucionalidade, não retornou do Senado à Câmara de Deputados após a emenda de redação realizada. Tal medida violadora da Constituição Federal provocou outra distorção jurídica, que foi a falta de oitiva pelo Congresso Nacional das populações indígenas afetadas pelo empreendimento.

A oitiva dos povos sobre os impactos de uma megaobra deve ser prévia à aprovação do empreendimento, sob pena de a consulta ser traduzida apenas como um registro de vontade da comunidade. $\bigcirc$ melhor processo decisório sobre o tema deve acolher o entendimento que a resposta apresentada pelas etnias vincula o administrador, principalmente, se for negativa aos interesses do Estado. $O$ direito de dizer não é garantido constitucionalmente aos consultados e deve ser respeitado pela administração pública, principalmente, se viola direitos fundamentais que podem representar o fim das etnias.

Decisões que autorizam megaobras, como Belo Monte e que são fundamentadas na ordem pública e, notadamente, na economia pública nacional, afrontam diretamente a vida das etnias autóctones. $O$ desenvolvimento humano dos povos indígenas passa exatamente pela possibilidade de se garantir a liberdade de auto-organização e autodeterminação. Ambas são condição para o desenvolvimento das capacidades individuais e coletivas dos grupos indígenas.

\section{Referências}

AGÊNCIA NACIONAL DE ENERGIA ELÉTRICA. Aneel. Potencial hidrelétrico brasileiro. In: Energia hidráulica. Brasília, DF, 2016. Disponível em: <http://www.aneel.gov.br/aplicacoes/atlas/ energia_hidraulica/4_3.htm >.Acesso em: 20 dez. 2016.

BRASIL. Congresso Nacional. Decreto Legislativo n. 788, de 13 de julho de 2005. Autoriza o Poder Executivo a implantar o Aproveitamento Hidroelétrico Belo Monte, localizado em trecho do Rio Xingu, no Estado do Pará, a ser desenvolvido após estudos de viabilidade pela Centrais Elétricas Brasileiras S.A. - Eletrobrás. Brasília, DF, 2005. Disponível em: <http://legis.senado.gov.br/legislacao/Lista TextoIntegral.action?id=231371 > . Acesso em: 20 jan. 2017.

BRASIL. Constituição da República Federativa do Brasil de 1988. Brasília, DF, 2000. Disponível em <http://www.planalto.gov.br/ccivil_03/constituicao/constituicao.htm>. Acesso em: 5 fev. 2017.

BRASIL. Decreto n. 96.652, de 6 de setembro de 1988. Aprova o Plano Nacional de Energia Elétrica 1987/2010 - Plano 2010 -, fixa diretrizes e normas para concessão ou autorização de centrais geradoras de energia elétrica no País e dá outras providências. Brasília, DF, 2005. Disponível em: <http://www.planalto.gov.br/ccivil_03/decreto/1980-1989/D96652.htm>. Acesso em: 11 nov. 2016. 
BRASIL. Decreto n. 5.051, de 19 de abril de 2004. Promulga a Convenção no 169 da Organização Internacional do Trabalho - OIT sobre Povos Indígenas e Tribais. Brasília, DF, 2004. Disponível em: <http://www.planalto.gov.br/ccivil_03/_ato2004-2006/2004/decreto/d5051.htm>. Acesso em: 02 fev. 2017.

BRASIL. Plano Nacional de Energia Elétrica 1987/2010. Relatório Executivo. Rio de Janeiro: Centrais Elétricas Brasileiras S. A. - Eletrobrás e Ministério das Minas e Energia - MME, dez.1987. Disponível em: <http://www.planalto.gov.br/ccivil_03/decreto/1980-1989/anexo/and96652-88.pdf>. Acesso em: 19 ago. 2014.

BRASIL. Potencial hidrelétrico brasileiro está entre os cinco maiores do mundo. Portal Brasil, Brasília, DF, 2011. Disponível em: <http://www.brasil.gov.br/infraestrutura/2011/12/potencial-hidreletrico-brasileiro-esta-entre-os-cinco-maiores-do-mundo >. Acesso em: 10 fev. 2017.

CENTRAIS ELÉTRICAS BRASILEIRAS. Eletrobrás. Atualização do Inventário Hidrelétrico da Bacia do Rio Xingu: alternativas locacionais de Belo Monte. 8892/00-3X-RL-0005-0. Rio de Janeiro: Eletrobrás, outubro de 2006. Disponível em: <https://www.eletrobras.com/ELB/services/DocumentManagement/FileDownload.EZTSvc.asp?DocumentID =\%7B940DEA02-C135-4F1B-8FBE-79A196C7DDBE\%7D\&ServiceInstUID=\%7B9F99B54C-E9F1-479F-A9B0-F08EFBF20600\%7D>. Acesso em: 11 jan. 2017.

CENTRAIS ELÉTRICAS BRASILEIRAS. Eletrobrás. Atualização do Inventário Hidrelétrico da Bacia do Rio Xingu. Consolidação dos Estudos Realizados. Relatório Geral. Volume I - Texto. Tomo I. Processo Aneel n. ${ }^{\circ}$ 48500.004313/05-47. 8892/00-10-RL-0001-0. Rio de Janeiro: Eletrobrás, 2007. p. 1-4.

CENTRAIS ELÉTRICAS BRASILEIRAS. Eletrobrás. Aproveitamento Hidrelétrico de Belo Monte: Relatório de Impacto Ambiental - RIMA. Rio de Janeiro: Eletrobrás, 2009. p. 46. Disponível em: <http://www.eletrobras.com/ELB/data/Pages/LUMIS46763BB8PTBRIE.htm>. Acesso em: 10 jan. 2017.

CENTRAIS ELÉTRICAS BRASILEIRAS. Eletrobrás. Sistema de informação do potencial hidrelétrico brasileiro - SIPOT. Rio de Janeiro, 2003.

FIGUEIRA NETTO, Carlos Alberto de Moya; FRANCO, Hélio Costa de Barros; REZENDE, Paulo Fernando Vieira. AHE Belo Monte: evolução dos estudos. In: COMITÊ BRASILEIRO DE BARRAGENS - XXVII SEMINÁRIO NACIONAL DE GRANDES BARRAGENS. 27., 2007, Pará. Anais eletrônicos...Pará, 2007. Disponível em: <http://www.eletrobras.gov.br/ELB/extranet/data/ documents/storedDocuments/\%7B5947E09B-BDF0-4A21-A48F-518B42072401\%7D/\%7BCA553E55-5660-4778-8CD7-6BCB07905B74\%7D/AHE\%20Belo\%20Monte\%20Evolu\%E7\%E3o\%20dos\%20 Estudos.pdf>. Acesso em: 10 jan. 2017.

IBGE. Área territorial brasileira. Consulta por Unidade da Federação. Brasília, DF, 2017. Disponível em: <http://www.ibge.gov.br/home/geociencias/areaterritorial/principal.shtm>. Acesso em: 20 jan. de 2017.

IBGE.Estados@. Brasília, DF, 2015.Disponível em: <http://www.ibge.gov.br/estadosat/perfil. php?sigla $=$ pa $>$. Acesso em: 20 jan. 2017.

INSTITUTO DE PESQUISA ECONÔMICA APLICADA. IPEA. O que é? Amazônia Legal. Revista Desafios do Desenvolvimento, Brasília, DF, edição 44, ano 5, n. 44, ago. 2008. Disponível em: <http:// www.ipea.gov.br/desafios/index.php?option $=$ com_content $\&$ id $=2154$ : catid $=28 \&$ Itemid $=23>$ Acesso em: 03 fev. 2017. 
INSTITUTO SOCIOAMBIENTAL. ISA. Cronologia do Projeto. Especial Belo Monte. Disponível em: <http://www.socioambiental.org/esp/bm/hist.asp>. Acesso em: 16 jan. 2017.

INSTITUTO SOCIOAMBIENTAL. ISA. Cronologia de um desastre anunciado. Movimento Xingu Vivo para sempre. Disponível em: <http://www.xinguvivo.org.br/2010/10/14/cronologia-de-um-desastre-anunciado/>. Acesso em: 02 fev. 2017.

MINISTÉRIO PÚBLICO FEDERAL. Ação Civil Pública Ambiental n. 2006.39.03.000711-8. Procuradoria da República no Município de Altamira. Pará: Altamira, 2006.

MINISTÉRIO PÚBLICO FEDERAL. Ação civil pública ambiental com pedido de liminar. Processo n. 2001.39.00.005867-6. Pará: Altamira, 2001.

MINISTÉRIO PÚBLICO FEDERAL. Ação civil pública combinada com ação de responsabilidade por ato de improbidade administrativa com requerimento de medida liminar. Processo $\mathrm{n}$. 2008.39.03.000071-9. Pará: Altamira, 2008.

PARÁ (Estado). Justiça Federal de $1^{a}$ Instância. Seção Judiciária do Estado Do Pará. Subseção Judiciária de Altamira. Vara Única. Sentença do processo n. 2006.39.03.000711-8. Juiz: Herculano Martins Nacif. Pará: Altamira, 27 de março de 2007. p. 4. Disponível em: <http://processual.trf1.jus.br/ consultaProcessual $/$ processo.php? proc $=200639030007118 \&$ secao $=$ ATM $>$. Acesso em: 06 fev. 2017.

PARÁ (Estado). Mapa do Estado do Pará. Pará, 2012. Disponível em: <http://pa.gov.br/O_Para/opara.asp>. Acesso em: 10 nov. 2016.

PEREIRA, Ana Karine Pereira. Desenvolvimentismo, conflito e conciliação de interesses na política de construção de hidrelétricas na amazônia brasileira. In: Texto para discussão. Brasília; Rio de Janeiro: IPEA, 2013. p. 19. Disponível em: <http://repositorio.ipea.gov.br/bitstream/11058/2001/1/ TD_1884.pdf>. Acesso em: 10 fev. 2017.

SEVÁ FILHO, Arsenio Oswaldo; SWITKES, Glenn. Tenotã Mõ: alertas sobre as consequências dos projetos hidrelétricos no rio Xingu. São Paulo: International Rivers Network, São Paulo, 2005.

SUPREMO TRIBUNAL FEDERAL. Ação Direta de Inconstitucionalidade n. 3.573/2005. Ministro Relator: Carlos Ayres Britto. Brasília: DF, 2005. Disponível em: <http://www.stf.jus.br/portal/processo/verProcessoAndamento.asp?incidente=2319559 >. Acesso em: 10 jan. 2017.

SUPREMO TRIBUNAL FEDERAL. Reclamação Constitucional n. 14404 MC / DF - Distrito Federal. Ministro Relator: Carlos Ayres Britto. Brasília, DF, 2012. Disponível em: <http://www.stf.jus. $\mathrm{br} /$ portal/jurisprudencia/listarJurisprudencia.asp?.s1 = \%28\%28reclama\%E7\%E3o+belo + monte\%29\%29+E+S\%2EPRES\%2E\&base=basePresidencia >. Acesso em: 23 jan. 2017.

SUPREMO TRIBUNAL FEDERAL. Suspensão Liminar n. 125. Ministra Relatora: Ellen Gracie. Brasília, DF, 2007. Disponível em: <http://www.stf.jus.br/portal/processo/verProcessoAndamento. asp? incidente $=2400547>$. Acesso em: 23 jan. 2017.

TRIBUNAL REGIONAL FEDERAL DA 1a REGIÃO. Agravo de Instrumento n. 2006. 01.00.017736-8/ PA. Desembargadora Federal Relatora: Selene Maria de Almeida. Brasília, DF, 24 de maio de 2006. Disponível em: <http://arquivo.trf1.jus.br/PesquisaMenuArquivo.asp?.p1=200601000177368\&pA $=200601000177368 \mathrm{xpN}=170064520064010000$ > . Acesso em: 30 jan. 2017 . 
TRIBUNAL REGIONAL FEDERAL DA 1ª REGIÃO. Apelação Cível n. 2006. 39.03.000711-8/PA. Desembargadora Federal Relatora: Selene Maria de Almeida. Brasília, DF, 14 de novembro de 2011. p. 8. Disponível em: <http://arquivo.trf1.jus.br/PesquisaMenuArquivo.asp?p1=200639030007118 \&pA $=200639030007118 \& \mathrm{pN}=7098820064013903>$. Acesso em: 30 jan. 2017.

TRIBUNAL REGIONAL FEDERAL DA 1ª REGIÃO. Apelação Cível n. 0025999-75.2010.4.01.3900/ PA. Desembargador Federal Relator: Souza Prudente. Brasília, DF, 2010. 26 de março de 2014. Disponível em: <http://processual.trf1.jus.br/consultaProcessual/processo.php? secao=TRF1\&pro$c=00259997520104013900 \& p g=1>$. Acesso em: 30 jan. 2017.

TRIBUNAL REGIONAL FEDERAL DA $1^{\mathrm{a}}$ REGIÃO. Embargos de Declaração n. 2006. 39.03.0007118/PA. Desembargador Federal Relator: Souza Prudente. Brasília, DF, 13 de agosto de 2012. p. 4-5. Disponível em: <http://arquivo.trf1.jus.br/PesquisaMenuArquivo.asp?.p1=200639030007118\&pA $=200639030007118 \& \mathrm{pN}=7098820064013903>$. Acesso em: 30 jan. 2017.

Data da submissão: 09 de março de 2017 Aceito em: 13 de abril de 2017 
